\section{Humic Acid and Boron to Minimize the Incidence of Alternate Bearing and Improve the Productivity and Fruit Quality of Mango Trees}

\author{
Hanan M. El-Hoseiny \\ Horticulture Research Institute, Agricultural Research Center (ARC), Giza, \\ 12619, Egypt
}

Mohamed N. Helaly

Agricultural Botany Department, Faculty of Agriculture, Mansoura University, Mansoura, 35516, Egypt

Nabil I. Elsheery

Agricultural Botany Department, Faculty of Agriculture, Tanta University, Tanta, 31527, Egypt

Shamel M. Alam-Eldein

Department of Horticulture, Faculty of Agriculture, Tanta University, Tanta, 31527, Egypt

Additional index words. biostimulants, malformation, micronutrients, osmostimulants, photosynthesis, phytohormones

\begin{abstract}
Mango production faces several challenges, such as nutrient deficiency, physiological stress, and alternate bearing, which eventually affect tree productivity. This study was carried out during the 2017 and 2018 seasons to evaluate the effect of single and combined applications of humic acid (as potassium humate; $0.15 \%, 0.30 \%$, $0.45 \%$ ) and boron (as boric acid; 300, $600 \mathrm{mg} \cdot \mathrm{L}^{-1}$ ) on 'Zebda' mango trees grown at Dir AlMalak region, Sharkeya Governorate, Egypt. Foliar spray was applied twice before flowering (first week of January and first week of February), and a third spray was applied by the beginning of flowering (first week of March) in both seasons. Humic acid and boron effectively enhanced tree growth, flowering, yield, and fruit quality. Humic acid was more effective than boron in this respect. Combined application of both materials surpassed the single application of each material on overall tree physiology and annual productivity. The observed results may be a consequence of the increase in tree photosynthetic pigments, nutrients, organic solutes, and phytohormones such as auxins, gibberellins, and cytokinins. The reduction in abscisic acid content may be related to the role of humic acid and boron protecting the plant against destructive oxidative reactions; improving the ability of the trees to withstand environmental stresses; thereby reduce floral malformation percentage, minimize the incidence of alternate bearing, and improve annual tree productivity and fruit quality. The most pronounced effect in this regard was noted with the application of $0.30 \%$ humic acid $+600 \mathrm{mg} \cdot \mathrm{L}^{-1}$ boric acid.
\end{abstract}

\footnotetext{
Received for publication 6 Apr. 2020. Accepted for publication 16 Apr. 2020.

Published online 20 May 2020.

The graduate students and research affairs sector of Tanta University, Egypt, funded this research under project code TU-03-13-06.

We gratefully thank the owner of the mango orchard and his staff for providing all required materials to do this research. Our appreciation also extends to the staff of Plant Science Laboratory of Horticulture Research Institute, Agricultural Research Center, for their excellent technical assistance.

S.M.A. is the corresponding author. E-mail: shamel@ufl.edu.

This is an open access article distributed under the CC BY-NC-ND license (https://creativecommons. org/licenses/by-nc-nd/4.0/).
}

Mango [Mangifera indica (L.)], a member of family Anacardiaceae, is considered one of the most important fruit tree grown in tropical and subtropical regions (Masroor et al., 2016). It is also considered the second cultivated tropical fruit, and the sixth major fruit crop worldwide (UNCTAD, 2016). It can be successfully cultivated in all irrigated semiarid regions, such as Egypt, which considered the most important mango producer in the Middle East that successfully grown a wide variety of mango cultivars (Elkhishen, 2015). Total cultivated area in Egypt is $\approx 78,847.6$ ha, and total annual production is $850,114.85 \mathrm{t}$ (Food and Agriculture Organization of the United Nation, 2018). Mango is mainly being cultivated in the Sharkeya, Ismailia, Fayoum, Qena, and Beheira Governorates. The most important varieties are Hindi, Taymour, Ewais, Zebda, Langara, Alphonse, and Keitt (Riad, 1997).

Mango production faces several challenges, such as micronutrients deficiency, biotic and abiotic stresses, and problems related to fruit yield and quality (Kumar and Kumar, 2016). Alternate bearing; high fruiting in a year ("on-year") and unsatisfactory fruiting in the next year ("off-year"), as well as low fruit set and fruit retention are the main reasons of low yield in mango (Saker and Rahim, 2013). Most of the Egyptian mango cultivars, particularly Zebda, suffer from alternate bearing (Shaban, 2009a). The variation in temperature or humidity during flowering, pollination, fruit set or maturation, in addition to the depletion in tree reserves during the period of heavy crop load, and vigorous vegetative growth with high levels of gibberellins during flower bud differentiation period, as well as the imbalance in carbon:nitrogen $(\mathrm{C} / \mathrm{N})$ ratio have been considered some of the major causes for alternate bearing in mango (Chadha, 1993). Some field practices, such as foliar spray of organic biostimulants (e.g., humic acid, fulvic acid, and amino acids) and micronutrients (e.g., $\mathrm{Fe}, \mathrm{Zn}, \mathrm{Mn}, \mathrm{Cu}$, and $\mathrm{B}$ ), were used to improve 'Keitt' and 'Ewais' mango fruit quantity and quality (El-Kosary et al., 2011). Humic acid directly absorbed by leaves, resulting in low energy consumption, metabolism improvement, and stress mitigation, which in turn promote plant growth and productivity (Yakhin et al., 2017). A combined foliar application of $\mathrm{N}$ and $\mathrm{B}$ has alleviated the incidence of alternate bearing in 'Zebda' mango by $41 \%$ and improved yield by 5.9 fold compared with the untreated trees during the off-year (El-Motaium et al., 2019). Under salinity stress conditions, the application of $\mathrm{ZnO}$ and Si nanoparticles has improved plant resistance to salinity, reduced floral malformation percentage, minimized the incidence of alternate bearing, and improved annual productivity and fruit quality of 'Ewais' mango trees (Elsheery et al., 2020).

Humic acid (HA) is the active constituent of organic humus. It is not considered a fertilizer; instead, it is used as a soil conditioner or as a plant biostimulant (Ngullie et al., 2014). Humic acid directly and indirectly affects plant growth and development (Chen et al., 2004). It stimulates enzymes in many biological processes, enhances plant resistance to biotic stress, improves chlorophyll synthesis and photosynthesis rate, promotes sugars and amino acids metabolism, and increases cell wall thickness prolonging fruit storage period (Abd El-Razek et al., 2012; Hagagg et al., 2013). Humic acid application on mango trees induced nutrient uptake and enhanced vegetative growth, flowering and fruiting characteristics (Pablo Morales and William, 2003). However, the action of humic acid is dose dependent; for instance, high concentrations are inhibitory for nutrient accumulation (Chen and Avaid, 
1990). Application of HA increased P content in leaves of 'Florida Prince' peach trees (Abd El-Razek et al., 2012). Humic acid improved shoot length and diameter, leaf area, fruit weight, dimensions, firmness, anthocyanin content, total soluble solids (TSS), TSS/acid ratio, and decreased the percentage of fruit drop and acidity in 'Anna' apple (Mosa et al., 2015). A positive correlation between fruit yield and leaf nutrients content was noticed with the application of HA on 'Red Delicious' apple trees (Hidayatullah et al., 2018). Humic acid increased fruit TSS and total sugars but reduced acidity of 'Ewais' mango fruit (El-Kosary et al., 2011).

Boron (B) is a critical nonmetal immobile micronutrient, important for plant growth and development, pollen germination, and pollen tube elongation (Saini et al., 2019). It has a role in cell wall synthesis, structure and lignification, and plasma membrane integrity (Srivastava and Gupta, 1996). Careful application of $B$ is important because of the narrow threshold between B deficiency and toxicity (Yua and Ryan, 2008). Boron improves enzymes activity, promotes phytohormones and nucleic acids, activates nutrient uptake and mitigates plant tolerance to salinity, increases carbohydrates and sugars allocation, and stimulates phenols metabolism (Khayyat et al., 2007; Marschner, 2012). Boron foliar spray on 'Dashehari' mango trees during the off-years has increased $\mathrm{C} / \mathrm{N}$ ratio and ultimately improved flowering, fruit set, number of fruit per tree, and total yield (Negi et al., 2009). Foliar spray of B and putrescine significantly decreased fruit drop percentage and improved fruit yield and quality of 'Zebda' mango (Ali et al., 2017). A mixture of $\mathrm{Fe}, \mathrm{B}$, and $\mathrm{Zn}$ increased nutrient uptake and improved fruit quality of 'Dusehri' mango (Anees et al., 2011) and 'Bhaskara' cashew (Lakshmipathi et al., 2018).

Most of the previous reports have focused on plant response to soil application of humic acid. Limited reports have shed light on foliar application of humic acid on fruit tree, and mango in particular. The aim of this study was to evaluate the effect of foliar spray with humic acid and boron on minimizing the incidence of alternate bearing and improving the yield and fruit quality of 'Zebda' mango trees grown under the Egyptian conditions.

\section{Materials and Methods}

Experiment. This research was carried out on 15-year-old mango trees [Mangifera indica (L.) 'Zebda'] in a private orchard located at Dir AlMalak Valley, Sharkeya Governorate (lat. $30^{\circ} 73^{\prime} 27^{\prime \prime} \mathrm{N}$, long. 31 $71^{\prime} 95^{\prime \prime} \mathrm{E}$ ), Egypt, during two consecutive seasons; 2017 off-year and 2018 on-year. Thirty-six 'Zebda' mango trees from polyembryonicseeds, planted at $7 \times 7 \mathrm{~m}$ spacing, similar in vigor and size, lacking any symptoms of nutrients deficiency nor diseases, were chosen for this experiment. Trees were grown in sandy soil and subjected to drip irrigation at approximate daily rate of 8 to $10 \mathrm{~L} \cdot \mathrm{h}^{-1}$ based on weather conditions (e.g., temperature, trees (i.e., shoot growth, flowering, and fruiting). Soil analysis was carried out according to Klute and Dirksen (1986), and data are displayed in Table 1.

During both seasons, foliar spray of humic acid (HA) [as potassium humate $\left(\mathrm{C}_{9} \mathrm{H}_{8}\right.$ $\left.\mathrm{K}_{2} \mathrm{O}_{4}\right), 12 \% \mathrm{~K}_{2} \mathrm{O}$, imported from China by Humy Nasser Inc., Cairo, Egypt] at $0.15 \%$, $0.30 \%$, and $0.45 \%$; $\mathrm{B}$ [as boric acid (BA; $\mathrm{H}_{3} \mathrm{BO}_{3}$ ), Sigma Aldrich, St. Louis, MO] at 300 and $600 \mathrm{mg} \cdot \mathrm{L}^{-1}$, and their combinations was applied twice before flowering (first week of January and first week of February), and a third spray was applied after a month (first week of March) during flowering period (early March-early April). Control trees were also sprayed at the same three times using distilled water. Trees selected for this experiment were receiving other regular agricultural practices as the entire orchard. The experimental design was in a randomized complete block system of 12 treatments with three replicates each. Each replicate was represented by one tree.

Leaf area. At full bloom (first week of April), leaf area $\left(\mathrm{cm}^{2}\right)$ of the fourth leaf from 10 branches at the top of the tree was estimated according to the formula of Ahmed and Morsy (1999): LA $=[0.70(\mathrm{~L} \times \mathrm{W})-$ 1.06]; where LA $=$ leaf area $\left(\mathrm{cm}^{2}\right), \mathrm{L}=$ maximum leaf length $(\mathrm{cm}), \mathrm{W}=$ maximum leaf width $(\mathrm{cm})$, and then average leaf area was calculated.

Leaf analysis. The same 10 leaves were used to determine the concentration of photosynthetic pigments; chlorophyll (a) and (b), and carotenoids (\%) according to Fadeel (1962), and the content of total flavonoids $[\mu \mathrm{g} / 100 \mathrm{~g}$ dry weight (DW)] according to Jordan et al. (1994) using a spectrophotometer (Model ultraviolet 9100; LabTech Inc., Hopkinton, MA). Percentage of nitrogen (N), phosphorus $(\mathrm{P})$, and potassium $(\mathrm{K})$ was also determined (Wilde et al., 1979). Total carbohydrates $\left(\mu \mathrm{g} \cdot \mathrm{g}^{-1} \mathrm{DW}\right)$ and sugars $\left(\mathrm{mg} \cdot \mathrm{g}^{-1}\right.$ DW) were estimated according to Dubois humidity, etc.) and the growth stage of the

et al. (1956) and Ackerson and Krieg (1977), respectively. Estimation of total free amino acids (Rosed, 1957), proline (Bates et al., 1973), and total phenols (Gao et al., 2006) $\left[\mu \mathrm{g} \cdot \mathrm{g}^{-1}\right.$ fresh weight $\left.(\mathrm{FW})\right]$ was also carried out. Phytohormones ( $\left.\mu \mathrm{g} \cdot \mathrm{g}^{-1} \mathrm{FW}\right)$; auxins [mainly indole-3-acetic acid (IAA)], gibberellins (mainly $\mathrm{GA}_{3}$ ), and abscisic acid (ABA) were determined according to Koshioka et al. (1983) using high performance liquid chromatography (M5 Micro flow HPLC system; SCIEX, Framingham, MA), whereas cytokinins (CKs) were determined using the methodology of Nicander et al. (1993).

Floral malformation assessment. At full bloom, trees were inspected for malformed floral panicles, which characterized by compacted, stunted, thickened, and branched panicles with larger flower number and size. Symptoms also included green and dwarfed panicles with distorted leaves growing instead of flowers (Helaly et al., 2018). The total number of panicles per tree was counted, and floral malformation percentage was calculated using the following equation:

\section{Malformation \% = \\ (Number of malformed panicles per tree \\ $\div$ Total number of panicles per tree) $\times 100$.}

Yield and fruit physiochemical characteristics. At commercial harvest time by late August-early September, yield was recorded as total fruit weight (kilograms) per tree. A sample of 10 ripe fruit per tree was randomly selected from the four directions (north, east, south, and west) and three levels (top, medium, and bottom) of the tree to calculate average fruit and pulp weight, in addition to fruit length and width. Fruit and pulp weight (grams) were measured using a bench-top digital scale Model PC-500 (Doran scales, Inc., Batavia, IL). Fruit length and width (millimeters) were measured using a digital caliper (Grizzly Industrial,

Table 1. Soil analysis of the experimental site (values are means of two seasons)

\begin{tabular}{|c|c|c|c|}
\hline & \multirow[b]{2}{*}{ Characteristics } & \multicolumn{2}{|c|}{ Soil depth $(\mathrm{cm})$} \\
\hline & & $0-30$ & $30-60$ \\
\hline \multirow[t]{6}{*}{ Physical } & Texture & \multicolumn{2}{|c|}{ Sandy } \\
\hline & Fine sand $(\%)$ & 29.44 & 34.12 \\
\hline & Coarse sand $(\%)$ & 67.2 & 62.23 \\
\hline & Silt $(\%)$ & 2.10 & 2.27 \\
\hline & Clay $(\%)$ & 1.26 & 1.38 \\
\hline & Field capacity $(\%)$ & 11 & 12 \\
\hline \multirow[t]{15}{*}{ Chemical } & Electrical conductivity $\left(\mathrm{dS} \cdot \mathrm{m}^{-1}\right)(1: 5$ extract $)$ & 0.46 & 0.42 \\
\hline & $\mathrm{pH}(1: 5$ extract $)$ & 8.11 & 8.23 \\
\hline & Organic matter $(\%)$ & 2.07 & 1.67 \\
\hline & $\mathrm{CaCO}_{3}(\%)$ & 1.6 & 1.6 \\
\hline & $\mathrm{N}(\%)$ & 0.074 & 0.086 \\
\hline & $\mathrm{P}(\mathrm{ppm})$ & 5.50 & 0.20 \\
\hline & $\mathrm{K}(\mathrm{ppm})$ & 4.59 & 0.19 \\
\hline & $\mathrm{K}^{+}\left(\mathrm{mEq} \cdot \mathrm{L}^{-1}\right)$ & 0.32 & 0.36 \\
\hline & $\mathrm{Na}^{+}\left(\mathrm{mEq} \cdot \mathrm{L}^{-1}\right)$ & 4.46 & 4.69 \\
\hline & $\mathrm{Mg}^{+2}\left(\mathrm{mEq} \cdot \mathrm{L}^{-1}\right)$ & 1.27 & 1.36 \\
\hline & $\mathrm{Ca}^{+2}\left(\mathrm{mEq} \cdot \mathrm{L}^{-1}\right)$ & 4.31 & 4.17 \\
\hline & $\mathrm{Cl}^{-}\left(\mathrm{mEq} \cdot \mathrm{L}^{-1}\right)$ & 4.27 & 3.96 \\
\hline & $\mathrm{SO}_{4}^{-}\left(\mathrm{mEq} \cdot \mathrm{L}^{-1}\right)$ & 4.86 & 6.14 \\
\hline & $\mathrm{CO}_{3}^{-}\left(\mathrm{mEq} \cdot \mathrm{L}^{-1}\right)$ & 0 & 0 \\
\hline & $\mathrm{HCO}_{3}^{-}\left(\mathrm{mEq} \cdot \mathrm{L}^{-1}\right)$ & 1.23 & 1.02 \\
\hline
\end{tabular}


Bellingham, WA). At room temperature $\left(\approx 22\right.$ to $\left.23{ }^{\circ} \mathrm{C}\right)$, TSS percentage was estimated using a handheld refractometer Model RA-130 (KEM Kyoto Electronics Manufacturing Co. Ltd., Tokyo, Japan). Total acidity, as grams citric acid per $100 \mathrm{~mL}$ juice, equivalent to \% citric acid (using phenolphthalein indicator), as well as total sugars, as grams per $100 \mathrm{~g}$ pulp, expressed as \% sugars were estimated according to Association of Official Analytical Chemists (1990).

Statistical analysis. The SPSS statistical analysis package (version 16; SPSS Inc., Chicago, IL) was used for data analysis. Data were statistically analyzed by analysis of variance, and means were compared using the least significant difference test at $P \leq$ 0.05 (Snedecor and Cochran, 1980).

\section{Results and discussion}

Leaf area and photosynthetic pigments. Results displayed in Table 2 indicated that untreated 'Zebda' mango trees recorded the lowest values of leaf area and photosynthetic pigments in both seasons. The single application of either HA or BA at any concentration was only effective in improving leaf area and chlorophyll (a) content compared with the control, whereas the effect on chlorophyll (b) was only noticeable with the highest concentration of either HA or BA application during both seasons. The main effect of HA or BA was not significant compared with the control in regard to carotenoids content in both season. On the other hand, the combined application of HA and BA at any concentration significantly improved leaf area and photosynthetic pigments during both seasons. The most pronounced effect in this regard was referred to the combined application of $0.30 \% \mathrm{HA}+600 \mathrm{mg} \cdot \mathrm{L}^{-1} \mathrm{BA}$, followed by $0.15 \% \mathrm{HA}+600 \mathrm{mg} \cdot \mathrm{L}^{-1} \mathrm{BA}$. The difference between both treatments was insignificant in regard to the carotenoids content only. Increasing the concentration of $\mathrm{HA}$ and $\mathrm{BA}$ (i.e., $0.45 \% \mathrm{HA}+600 \mathrm{mg} \cdot \mathrm{L}^{-1} \mathrm{BA}$ ) led to a significant reduction in leaf area and chlorophyll (a), whereas no effect was noticed on chlorophyll (b) and carotenoids compared with $0.15 \% \mathrm{HA}+600 \mathrm{mg} \cdot \mathrm{L}^{-1} \mathrm{BA}$. The difference was also significant compared with $0.30 \% \mathrm{HA}+600 \mathrm{mg} \cdot \mathrm{L}^{-1} \mathrm{BA}$ in regard to leaf area, and chlorophyll (a) and (b). The reduction in leaf area and chlorophyll content with the application of $0.45 \% \mathrm{HA}+600$ $\mathrm{mg} \cdot \mathrm{L}^{-1}$ BA could be due to the inhibitory effect of the high concentrations of both HA (Chen and Avaid, 1990) and BA (Yua and Ryan, 2008).

The role of HA on leaf area and chlorophyll synthesis has been reported in tomato (Turkmen et al., 2004) and corn (Khan et al., 2019). Humic acid significantly increased chlorophyll (a) and (b), total chlorophyll, and carotenoids in faba bean (El-Ghamry et al., 2009) and pearl millet plants (Hassanein et al., 2017). The availability of HA was might be responsible of increasing photosynthesis rate, and hence leaf area of salt-stressed bean plants (Aydin et al., 2012). The positive effect of HA on leaf area and photosynthetic pigments of 'Zebda' mango (Table 2) is consistent with the previous reports. Humic acid increased $\mathrm{N}$ and $\mathrm{NO}_{3}$ uptake, which enhanced $\mathrm{N}$ metabolism and protein production, and thereby increased chlorophyll content (Haghighi et al., 2012). Humic acid also increased cell membrane permeability, oxygen uptake, respiration and photosynthesis rate, phosphorus uptake, and root elongation (Rajpar et al., 2011). It was also reported that HA induces $\mathrm{H}^{+}$-ATPase activity in plasma membrane and promotes plant growth (Dobbss et al., 2010) throughout the increase in lateral root emergence and overall root absorbance (Schmidt et al., 2007).

A significant increase in leaf area of 'Feutrell's Early' mandarin with foliar spray of B has been reported (Khan et al., 2012). This may be due to the stimulating role of $\mathrm{B}$ in cell division, elongation, and turgor pressure (Camacho-Cristóbal et al., 2015). As with the results of the present study (Table 2), it was previously reported that foliar spray of $\mathrm{B}$ at flowering stage significantly improved total chlorophyll, and chlorophyll (a) and (b) in 'Frantoio' olive leaves (Hegazi et al., 2018). The combined application of $\mathrm{Zn}$ and $\mathrm{B}$ improved the biosynthesis of chlorophyll (a) and (b), total chlorophyll, and carotenoids, as well as leaf area, which in turn increased 'Bhaskara' cashew nut production (Lakshmipathi et al., 2018). A mixture of Si and $\mathrm{B}$ significantly increased shoot height and leaf area of wheat plants, as well as the grain yield per plant (Hanafy et al., 2008). A positive correlation was reported between leaf area and B concentration in plant shoots (Eggert and von Wiren, 2017), and this is consistent with the results shown in Table 2. Increasing B concentration enhanced the production of brassinosteroid, which enhanced cell elongation and differentiation, and stabilized pectin fractions in cell wall (Wolf et al., 2014). Both HA and B increased chlorophyll and nutrient content, and thus photosynthesis rate in 'Kesar' mango. This effect could be attributed to the improvement in $\mathrm{N}$ and $\mathrm{K}$ uptake, which involved in chloroplast formation and chlorophyll biosynthesis (Ngullie et al., 2014).

Leaf $N-P-K$ content. Results displayed in Table 3 indicated variations among all three macronutrients in response to foliar application of HA and BA. The single application of $\mathrm{BA}$ at high concentration $\left(600 \mathrm{mg} \cdot \mathrm{L}^{-1}\right)$ and all levels of combined application of HA and $\mathrm{BA}$ increased $\mathrm{N}$ uptake compared with the control during both seasons. Although the treatment of $0.30 \% \mathrm{HA}+600 \mathrm{mg} \cdot \mathrm{L}^{-1} \mathrm{BA}$ was the most effective in increasing $\mathrm{N}$ concentration, the difference was not significant compared with all other combined treatments in both seasons but was significant compared with $600 \mathrm{mg} \cdot \mathrm{L}^{-1} \mathrm{BA}$ during the second season only. For $\mathrm{P}$ concentration, the single application of $0.45 \% \mathrm{HA}$, as well as the combined application of $300 \mathrm{mg} \cdot \mathrm{L}^{-1} \mathrm{BA}$ with any concentration of $\mathrm{HA}$, significantly improved $\mathrm{P}$ level compared with the control in both seasons. The most pronounced effect was referred to the application of $0.15 \%$ $\mathrm{HA}+300 \mathrm{mg} \cdot \mathrm{L}^{-1} \mathrm{BA}$; however, the difference was insignificant compared with all other combined treatments, except $0.45 \%$ $\mathrm{HA}+600 \mathrm{mg} \cdot \mathrm{L}^{-1} \mathrm{BA}$ that significantly reduced $\mathrm{P}$ concentration in both seasons. In regard to $\mathrm{K}$ concentration, all treatments significantly improved $\mathrm{K}$ content compared with the control during both seasons, except for $0.15 \%$ HA that was only effective during the first season. The highest $\mathrm{K}$ value was recorded with the application of $0.30 \% \mathrm{HA}+600$ $\mathrm{mg} \cdot \mathrm{L}^{-1} \mathrm{BA}$, which was significantly different from all other treatments. Control recorded the lowest $\mathrm{N}-\mathrm{P}-\mathrm{K}$ values in both seasons. These results indicate that both $\mathrm{N}$ and $\mathrm{K}$ were

Table 2. Effect of humic acid (HA) and boron [as boric acid (BA)] on leaf area and photosynthetic pigments of 'Zebda' mango trees during 2017 and 2018 seasons.

\begin{tabular}{|c|c|c|c|c|c|c|c|c|}
\hline \multirow[b]{2}{*}{ Treatments } & \multicolumn{2}{|c|}{ Leaf area $\left(\mathrm{cm}^{2}\right)$} & \multicolumn{2}{|c|}{ Chlorophyll (a) (\%) } & \multicolumn{2}{|c|}{ Chlorophyll (b) (\%) } & \multicolumn{2}{|c|}{ Carotenoids (\%) } \\
\hline & 2017 & 2018 & 2017 & 2018 & 2017 & 2018 & 2017 & 2018 \\
\hline Control & 56.6 & 57.4 & 6.2 & 6.4 & 3.1 & 3.3 & 2.0 & 2.2 \\
\hline $0.15 \% \mathrm{HA}$ & 58.1 & 58.7 & 6.5 & 6.6 & 3.2 & 3.2 & 2.3 & 2.3 \\
\hline $0.30 \% \mathrm{HA}$ & 60.4 & 60.8 & 6.6 & 6.6 & 3.2 & 3.3 & 2.3 & 2.4 \\
\hline $0.45 \% \mathrm{HA}$ & 61.8 & 62.3 & 6.7 & 6.8 & 3.4 & 3.5 & 2.5 & 2.5 \\
\hline $300 \mathrm{mg} \cdot \mathrm{L}^{-1} \mathrm{BA}$ & 59.3 & 60.1 & 6.6 & 6.7 & 3.3 & 3.4 & 2.4 & 2.5 \\
\hline $600 \mathrm{mg} \cdot \mathrm{L}^{-1} \mathrm{BA}$ & 61.3 & 62.2 & 6.8 & 6.9 & 3.5 & 3.6 & 2.5 & 2.6 \\
\hline $0.15 \% \mathrm{HA}+300 \mathrm{mg} \cdot \mathrm{L}^{-1} \mathrm{BA}$ & 61.4 & 62.4 & 7.0 & 7.1 & 3.7 & 3.8 & 2.8 & 2.9 \\
\hline $0.30 \% \mathrm{HA}+300 \mathrm{mg} \cdot \mathrm{L}^{-1} \mathrm{BA}$ & 62.2 & 63.3 & 7.1 & 7.3 & 3.9 & 3.9 & 2.9 & 2.9 \\
\hline $0.45 \% \mathrm{HA}+300 \mathrm{mg} \cdot \mathrm{L}^{-1} \mathrm{BA}$ & 63.3 & 64.2 & 7.2 & 7.3 & 4.1 & 4.0 & 3.0 & 3.1 \\
\hline $0.15 \% \mathrm{HA}+600 \mathrm{mg} \cdot \mathrm{L}^{-1} \mathrm{BA}$ & 65.8 & 65.7 & 7.6 & 7.8 & 4.1 & 4.1 & 3.2 & 3.2 \\
\hline $0.30 \% \mathrm{HA}+600 \mathrm{mg} \cdot \mathrm{L}^{-1} \mathrm{BA}$ & 67.3 & 68.7 & 7.9 & 8.1 & 4.3 & 4.4 & 3.5 & 3.6 \\
\hline $0.45 \% \mathrm{HA}+600 \mathrm{mg} \cdot \mathrm{L}^{-1} \mathrm{BA}$ & 63.2 & 64.1 & 7.4 & 7.6 & 4.0 & 4.1 & 3.1 & 3.2 \\
\hline Least significant difference $(P \leq 0.05)$ & 1.11 & 0.99 & 0.07 & 0.04 & 0.11 & 0.13 & 0.70 & 0.43 \\
\hline
\end{tabular}


highly responsive to the application of $0.30 \%$ $\mathrm{HA}+600 \mathrm{mg} \cdot \mathrm{L}^{-1} \mathrm{BA}$, similar to leaf area and photosynthetic pigments, whereas $\mathrm{P}$ highest concentration was more related to the lowest concentrations of both $\mathrm{HA}$ and $\mathrm{BA}$ (i.e., $\left.0.15 \% \mathrm{HA}+300 \mathrm{mg} \cdot \mathrm{L}^{-1} \mathrm{BA}\right)$.

Previous reports confirmed the role of HA increasing $\mathrm{N}-\mathrm{P}-\mathrm{K}$ content in faba bean plants grown in clayey soil (El-Ghamry et al., 2009) and drought-stressed pearl millet plants (Hassanein et al., 2017) due to the increase in root growth and development, thereby improving water and nutrient uptake, and hence plant tolerance to environmental stresses (Canellas et al., 2015). Under salinity stress conditions, HA increased $\mathrm{N}-\mathrm{P}-\mathrm{K}$ uptake in pepper plants (Cimrin et al., 2010). The positive role of HA could be due to the hormone-like activity of some HA components or may be related to IAA-independent mechanism, which might be activated by HA (Trevisan et al., 2011). In addition, HA contains phenolic, acidic, amino and quinine groups, which improve nutrient availability in calcareous alkaline soil that are poor in organic matter (Gaines and Yilmaz, 1983) and $\mathrm{N}$ content (Khan et al., 2019). Application of HA improved the permeability of root cells (Vaughan and Ord, 1981), hormonal and reactive oxygen species (ROS) balance (Can et al., 2008), macro- and micronutrient uptake (Arslan and Pehlivan, 2008), and pri- mary and secondary metabolism (Zanin et al., 2019), which eventually reflected on overall plant growth and development (Canellas and Olivares, 2014).

Boron enhanced N-P-K uptake and photosynthesis rate (Hermans et al., 2006). Spraying B, either alone or combined with $\mathrm{Zn}$, increased K content in 'Feutrell's Early' mandarin leaves (Khan et al., 2012). Boron application improved $\mathrm{P}$ concentration in wheat grains (Irfan et al., 2019). Foliar application of B caused changes in the concentration of other nutrients, possibly due to the interactions in ion uptake and transport (Bonilla et al., 2004). The increase in $P$ uptake with B application indicated their synergistic relationship (Huang et al., 2012), which ultimately enhanced biomass production in rapeseed (Lei et al., 2009). Boron is also an essential micronutrient in $\mathrm{N}$ metabolism and water relations (Marschner, 2012).

Carbohydrates and osmostimulants. Foliar spray of HA, BA, and their combinations was generally effective in carbohydrates and osmostimulants content in 'Zebda' mango leaves. Likewise leaf area, photosynthetic pigments, $\mathrm{N}$ and $\mathrm{K}$ content, the application of $0.30 \% \mathrm{HA}+600 \mathrm{mg} \cdot \mathrm{L}^{-1} \mathrm{BA}$ was the most effective treatment in carbohydrate and osmostimulant content compared with the control during both seasons (Tables 4 and

Table 3. Effect of humic acid (HA) and boron [as boric acid (BA)] on the percentage of nitrogen (N), phosphorus $(\mathrm{P})$, and potassium $(\mathrm{K})$ in leaves of 'Zebda' mango trees during 2017 and 2018 seasons.

\begin{tabular}{|c|c|c|c|c|c|c|}
\hline \multirow[b]{2}{*}{ Treatments } & \multicolumn{2}{|c|}{$N(\%)$} & \multicolumn{2}{|c|}{$\mathrm{P}(\%)$} & \multicolumn{2}{|c|}{$\mathrm{K}(\%)$} \\
\hline & 2017 & 2018 & 2017 & 2018 & 2017 & 2018 \\
\hline Control & 1.43 & 1.46 & 0.21 & 0.21 & 1.18 & 1.20 \\
\hline $0.15 \% \mathrm{HA}$ & 1.48 & 1.51 & 0.24 & 0.25 & 1.23 & 1.23 \\
\hline $0.30 \% \mathrm{HA}$ & 1.54 & 1.57 & 0.27 & 0.27 & 1.25 & 1.26 \\
\hline $0.45 \% \mathrm{HA}$ & 1.63 & 1.65 & 0.29 & 0.30 & 1.28 & 1.29 \\
\hline $300 \mathrm{mg} \cdot \mathrm{L}^{-1} \mathrm{BA}$ & 1.58 & 1.61 & 0.26 & 0.27 & 1.26 & 1.27 \\
\hline $600 \mathrm{mg} \cdot \mathrm{L}^{-1} \mathrm{BA}$ & 1.66 & 1.67 & 0.28 & 0.28 & 1.29 & 1.31 \\
\hline $0.15 \% \mathrm{HA}+300 \mathrm{mg} \cdot \mathrm{L}^{-1} \mathrm{BA}$ & 1.68 & 1.68 & 0.35 & 0.36 & 1.34 & 1.35 \\
\hline $0.30 \% \mathrm{HA}+300 \mathrm{mg} \cdot \mathrm{L}^{-1} \mathrm{BA}$ & 1.71 & 1.72 & 0.34 & 0.34 & 1.35 & 1.36 \\
\hline $0.45 \% \mathrm{HA}+300 \mathrm{mg} \cdot \mathrm{L}^{-1} \mathrm{BA}$ & 1.75 & 1.75 & 0.29 & 0.28 & 1.37 & 1.39 \\
\hline $0.15 \% \mathrm{HA}+600 \mathrm{mg} \cdot \mathrm{L}^{-1} \mathrm{BA}$ & 1.77 & 1.78 & 0.28 & 0.29 & 1.41 & 1.41 \\
\hline $0.30 \% \mathrm{HA}+600 \mathrm{mg} \cdot \mathrm{L}^{-1} \mathrm{BA}$ & 1.81 & 1.83 & 0.28 & 0.30 & 1.46 & 1.48 \\
\hline $0.45 \% \mathrm{HA}+600 \mathrm{mg} \cdot \mathrm{L}^{-1} \mathrm{BA}$ & 1.75 & 1.76 & 0.27 & 0.28 & 1.38 & 1.39 \\
\hline Least significant difference $(P \leq 0.05)$ & 0.21 & 0.15 & 0.07 & 0.04 & 0.03 & 0.05 \\
\hline
\end{tabular}

5). Application of $0.15 \% \mathrm{HA}+600 \mathrm{mg} \cdot \mathrm{L}^{-1}$ BA was the second most effective treatment, affecting all parameters except sugar content, where the application of $0.45 \% \mathrm{HA}+600$ $\mathrm{mg} \cdot \mathrm{L}^{-1} \mathrm{BA}$ was the second most effective treatment and significantly differed from $0.30 \% \mathrm{HA}+600 \mathrm{mg} \cdot \mathrm{L}^{-1} \mathrm{BA}$. Treatment $0.15 \% \mathrm{HA}+600 \mathrm{mg} \cdot \mathrm{L}^{-1}$ BA ranked third in regard to sugar content (Table 4). However, the difference between $0.30 \% \mathrm{HA}+600$ $\mathrm{mg} \cdot \mathrm{L}^{-1} \mathrm{BA}$ and $0.15 \% \mathrm{HA}+600 \mathrm{mg} \cdot \mathrm{L}^{-1}$ $\mathrm{BA}$ was only significant in terms of sugar and proline content in both seasons (Tables 4 and 5 , respectively). The increase in carbohydrates and osmostimulants may be considered a direct result of the high rate of photosynthesis due to large photosynthetic area and pigment content, which were positively affected by $0.30 \% \mathrm{HA}+600 \mathrm{mg} \cdot \mathrm{L}^{-1}$ BA treatment (Table 2).

The complex nature of biostimulant composition and the variety of molecules they contain make it difficult to know which components are the most active. Their effect is not due to a single component; instead, it is the consequence of the interaction of different components (Bulgari et al., 2019). They were able to modify some molecular processes, and enhanced primary and secondary metabolism (Yakhin et al., 2017) that might improve plant water and nutrient use efficiency, stimulate growth and development, and improve plant tolerance to abiotic stress (Van Oosten et al., 2017). Phenols are one of the most important groups of secondary metabolites in plants (Boud, 2007). Their concentration is seasonal and depends on the plant development stage (Ozyigit et al., 2007). Photo inhibition and nutrient deficiency such as $\mathrm{N}, \mathrm{P}, \mathrm{K}, \mathrm{S}, \mathrm{Mg}, \mathrm{Fe}$, and $\mathrm{B}$ triggers the synthesis of phenols (Dixon and Paiva, 1995) and flavonoids, which improve plant tolerance to stress conditions (Balasundram et al., 2006). Free amino acids are derived from protein hydrolysis (Colla et al., 2015). Proline is one of the common amino acids that improve plant tolerance to environmental stresses (Nanjo et al., 1999). Carbohydrates, proteins, amino acids, and lipids may increase stress tolerance throughout different stages of plant growth and development (Van Oosten et al., 2017). Amino

Table 4. Effect of humic acid (HA) and boron [as boric acid (BA)] on carbohydrates, sugars, and flavonoids content in leaves of 'Zebda' mango trees during 2017 and 2018 seasons.

\begin{tabular}{|c|c|c|c|c|c|c|}
\hline \multirow[b]{2}{*}{ Treatments } & \multicolumn{2}{|c|}{ Total carbohydrates $\left(\mu \mathrm{g} \cdot \mathrm{g}^{-1} \mathrm{DW}\right)$} & \multicolumn{2}{|c|}{ Total sugars $\left(\mathrm{mg} \cdot \mathrm{g}^{-1} \mathrm{DW}\right)$} & \multicolumn{2}{|c|}{ Total flavonoids $(\mu \mathrm{g} / 100 \mathrm{~g}$ DW $)$} \\
\hline & 2017 & 2018 & 2017 & 2018 & 2017 & 2018 \\
\hline $0.15 \% \mathrm{HA}$ & 176.4 & 179.2 & 19.6 & 19.8 & 7.3 & 7.4 \\
\hline $300 \mathrm{mg} \cdot \mathrm{L}^{-1} \mathrm{BA}$ & 181.7 & 181.9 & 20.4 & 20.8 & 7.5 & 7.6 \\
\hline $600 \mathrm{mg} \cdot \mathrm{L}^{-1} \mathrm{BA}$ & 183.7 & 184,6 & 21.1 & 21.3 & 7.7 & 7.8 \\
\hline $0.15 \% \mathrm{HA}+300 \mathrm{mg} \cdot \mathrm{L}^{-1} \mathrm{BA}$ & 188.7 & 189.3 & 22.6 & 22.8 & 7.9 & 8.0 \\
\hline $0.15 \% \mathrm{HA}+600 \mathrm{mg} \cdot \mathrm{L}^{-1} \mathrm{BA}$ & 196.5 & 196.8 & 25.4 & 25.6 & 8.6 & 8.6 \\
\hline $0.30 \% \mathrm{HA}+600 \mathrm{mg} \cdot \mathrm{L}^{-1} \mathrm{BA}$ & 199.6 & 199.8 & 27.7 & 27.8 & 9.2 & 9.4 \\
\hline $0.45 \% \mathrm{HA}+600 \mathrm{mg} \cdot \mathrm{L}^{-1} \mathrm{BA}$ & 191.2 & 192.4 & 25.8 & 26.3 & 8.5 & 8.6 \\
\hline Least significant difference $(P \leq 0.05)$ & 2.11 & 3.66 & 1.07 & 1.09 & 1.21 & 0.25 \\
\hline
\end{tabular}


acids affect $\mathrm{K}$ efflux through cell membrane improving plant tolerance to salinity (Cuin and Shabala, 2007). Amino acids may also play a role in increasing plant cold tolerance (Botta, 2013). Increase in $\mathrm{N}$ and photosynthesis rate resulted in the accumulation of amino acids and sugars necessary to regulate plant biological activities and maintain cell integrity (Ratthaphol et al., 2017).

Humic acid enhanced drought tolerance of kentucky bluegrass (Nabati, 1991) and salinity tolerance of tomato seedlings (Turkmen et al., 2004) due to the increase in proline level (Demir et al., 1999) and phenolic compounds (Aslam et al., 2016). A decrease in proline content and increase in nutrient uptake have been reported with exogenous application of HA on salt-stressed tomato plants (Farahat et al., 2012). Humic acid also affects enzyme activity and plant secondary metabolism (Canellas and Olivares, 2014), as well as plant respiration and photosynthesis, which in turn affect carbohydrate level (Nardi et al., 2007), protein synthesis (Carletti et al., 2008), and sugar and amino acid metabolism (Boehme et al., 2005). These reports are consistent with results in Tables 2-5. Similarly, HA improves tolerance to environmental stress through hormonal regulation (Cimrin et al., 2010), which reflected on membrane permeability, protein synthesis, and root elongation (Saruhan et al., 2011). These findings could be related to the regulation of $\mathrm{C} / \mathrm{N}$ ratio and its role in alternate bearing of mango trees.

Boron has been reported to improve the metabolism of phenolic compounds in 'Manaki' olive trees (Liakopoulos and Karabourniotis, 2005) due to the increase in gene expression responsible of phenolic compound biosynthesis (Manas et al., 2014; Song et al., 2015). Boron has also a positive role in the synthesis of nucleic acids, carbohydrate metabolism and transport from source to sink, and total plant biomass (Oyinlola, 2007) due to the increase in enzyme activity and carbon assimilation (Han et al., 2008), as well as sugar and carbohydrate metabolism (Hansch and Mendel, 2009). Pommerrenig et al. (2019) reported a reduction in sucrose transport from source to sink under B deficiency conditions. Foliar spray of B and $\mathrm{Zn}$ increased total sugars in papaya (Singh et al., 2005), 'Khasi' mandarin (Babu and Yadav, 2005) and 'Dusehrifruit' mango (Anees et al., 2011), as well as total phenols in three olive cultivars (Saadati et al., 2013), pungent pepper (Manas et al., 2014), and 'Merlot' grape (Song et al., 2015). Combined deficiency of $P$ and $\mathrm{B}$ inhibits protein synthesis leading to inhibition of plant growth (Bould et al., 1983).

Phytohormones. All foliar applications of HA, BA, and their combinations have significantly increased the level of IAA, GA 3 , and CKs but decreased ABA level in 'Zebda' mango trees compared with the control in both 2017 and 2018 seasons (Table 6). In this regard, the most pronounced effect was referred to the combined application of $0.30 \%$ $\mathrm{HA}+600 \mathrm{mg} \cdot \mathrm{L}^{-1} \mathrm{BA}$. Application of $0.15 \%$ $\mathrm{HA}+600 \mathrm{mg} \cdot \mathrm{L}^{-1} \mathrm{BA}$ was the second affecting the content of all phytohormones, except for $\mathrm{GA}_{3}$. In addition, the difference between both treatments was only significant in regard to IAA and CKs. Treatment $0.45 \% \mathrm{HA}+600$ $\mathrm{mg} \cdot \mathrm{L}^{-1} \mathrm{BA}$ was the second most significant in regard to increasing $\mathrm{GA}_{3}$ level and was significantly different from $0.30 \% \mathrm{HA}+600$ $\mathrm{mg} \cdot \mathrm{L}^{-1} \mathrm{BA}$, whereas the difference was insignificant compared with $0.15 \% \mathrm{HA}+600$ $\mathrm{mg} \cdot \mathrm{L}^{-1} \mathrm{BA}$.

Humic acid improves plant growth due to hormone-like activity, particularly IAA (Quaggiotti et al., 2004), which enhances $\mathrm{H}^{+}$ pumping through the plasma membrane; lowering of cell wall $\mathrm{pH}$; and initiating a cell wall loosening process and cell enlargement (Hager, 2003). Humic acid also acts as a hormonal balance and affects the emergence of lateral roots, improving water absorbance and nutrient uptake under stress conditions (Canellas et al., 2015). Increasing CK level with IAA could result in increased vegetative growth, photosynthetic pigments, yield, and fruit quality of 'Chemlali' olive trees (Dabbaghi et al., 2018) and potato plants (Ekin, 2019). Humic substances improve plant tolerance to environmental stress through the regulation effect on phytohormone levels,

Table 5. Effect of humic acid (HA) and boron [as boric acid (BA)] on free amino acids, proline, and phenols content in leaves of 'Zebda' mango trees during 2017 and 2018 seasons.

\begin{tabular}{|c|c|c|c|c|c|c|}
\hline \multirow[b]{2}{*}{ Treatments } & \multicolumn{2}{|c|}{ Total free amino acids $\left(\mu \mathrm{g} \cdot \mathrm{g}^{-1} \mathrm{FW}\right)$} & \multicolumn{2}{|c|}{ Proline $\left(\mu \mathrm{g} \cdot \mathrm{g}^{-1} \mathrm{FW}\right)$} & \multicolumn{2}{|c|}{ Total phenols $\left(\mu \mathrm{g} \cdot \mathrm{g}^{-1} \mathrm{FW}\right)$} \\
\hline & 2017 & 2018 & 2017 & 2018 & 2017 & 2018 \\
\hline $0.15 \%$ HA & 11.8 & 11.9 & 9.46 & 9.52 & 34.74 & 34.86 \\
\hline $300 \mathrm{mg} \cdot \mathrm{L}^{-1} \mathrm{BA}$ & 12.3 & 12.4 & 8.86 & 8.95 & 36.64 & 36.76 \\
\hline $600 \mathrm{mg} \cdot \mathrm{L}^{-1} \mathrm{BA}$ & 12.7 & 12.7 & 9.53 & 9.64 & 37.36 & 37.65 \\
\hline $0.15 \% \mathrm{HA}+300 \mathrm{mg} \cdot \mathrm{L}^{-1} \mathrm{BA}$ & 13.2 & 13.4 & 9.78 & 9.86 & 39.84 & 39.93 \\
\hline $0.15 \% \mathrm{HA}+600 \mathrm{mg} \cdot \mathrm{L}^{-1} \mathrm{BA}$ & 14.3 & 14.4 & 11.13 & 11.17 & 45.68 & 45.87 \\
\hline $0.30 \% \mathrm{HA}+600 \mathrm{mg} \cdot \mathrm{L}^{-1} \mathrm{BA}$ & 14.9 & 15.1 & 11.68 & 11.77 & 47.63 & 47.92 \\
\hline $0.45 \% \mathrm{HA}+600 \mathrm{mg} \cdot \mathrm{L}^{-1} \mathrm{BA}$ & 13.9 & 14.1 & 10.34 & 10.32 & 42.67 & 42.96 \\
\hline Least significant difference $(P \leq 0.05)$ & 0.72 & 0.71 & 0.53 & 0.41 & 2.01 & 1.79 \\
\hline
\end{tabular}

Table 6. Effect of humic acid (HA) and boron [as boric acid (BA)] on auxin (IAA), gibberellin (GA 3 ), cytokinins (CKs), and abscisic acid (ABA) content in leaves of 'Zebda' mango trees during 2017 and 2018 seasons.

\begin{tabular}{|c|c|c|c|c|c|c|c|c|}
\hline \multirow[b]{2}{*}{ Treatments } & \multicolumn{2}{|c|}{ IAA $\left(\mu \mathrm{g} \cdot \mathrm{g}^{-1} \mathrm{FW}\right)$} & \multicolumn{2}{|c|}{$\mathrm{GA}_{3}\left(\mu \mathrm{g} \cdot \mathrm{g}^{-1} \mathrm{FW}\right)$} & \multicolumn{2}{|c|}{$\mathrm{CKs}\left(\mu \mathrm{g} \cdot \mathrm{g}^{-1} \mathrm{FW}\right)$} & \multicolumn{2}{|c|}{$\mathrm{ABA}\left(\mu \mathrm{g} \cdot \mathrm{g}^{-1} \mathrm{FW}\right)$} \\
\hline & 2017 & 2018 & 2017 & 2018 & 2017 & 2018 & 2017 & 2018 \\
\hline $0.15 \% \mathrm{HA}$ & 14.58 & 14.62 & 18.64 & 18.68 & 11.66 & 11.69 & 1.24 & 1.21 \\
\hline $0.30 \% \mathrm{HA}$ & 14.85 & 14.93 & 19.82 & 19.87 & 11.75 & 11.79 & 1.18 & 1.15 \\
\hline $300 \mathrm{mg} \cdot \mathrm{L}^{-1} \mathrm{BA}$ & 14.93 & 15.15 & 19.91 & 19.97 & 11.61 & 11.65 & 1.21 & 1.19 \\
\hline $600 \mathrm{mg} \cdot \mathrm{L}^{-1} \mathrm{BA}$ & 15.22 & 15.26 & 20.13 & 20.17 & 11.73 & 11.77 & 1.17 & 1.16 \\
\hline $0.15 \% \mathrm{HA}+300 \mathrm{mg} \cdot \mathrm{L}^{-1} \mathrm{BA}$ & 15.56 & 15.62 & 22.14 & 22.17 & 12.02 & 12.11 & 1.15 & 1.13 \\
\hline $0.15 \% \mathrm{HA}+600 \mathrm{mg} \cdot \mathrm{L}^{-1} \mathrm{BA}$ & 16.24 & 16.27 & 24.65 & 24.68 & 12.31 & 12.33 & 1.06 & 1.05 \\
\hline $0.30 \% \mathrm{HA}+600 \mathrm{mg} \cdot \mathrm{L}^{-1} \mathrm{BA}$ & 16.74 & 16.72 & 26.37 & 26.45 & 12.63 & 12.67 & 1.03 & 1.03 \\
\hline $0.45 \% \mathrm{HA}+600 \mathrm{mg} \cdot \mathrm{L}^{-1} \mathrm{BA}$ & 15.93 & 15.97 & 24.82 & 24.93 & 12.27 & 12.32 & 1.11 & 1.09 \\
\hline Least significant difference $(P \leq 0.05)$ & 0.21 & 0.26 & 0.43 & 0.46 & 0.17 & 0.19 & 0.03 & 0.05 \\
\hline
\end{tabular}


particularly ABA (Cimrin et al., 2010). Saltstressed 'Zaghloul' date palm showed a reduction in IAA, $\mathrm{GA}_{3}$, and $\mathrm{CK}$ content with increased levels of ABA and ethylene (Helaly et al., 2016). Results in Table 6 show that 'Zebda' mango trees were not environmentally stressed.

Boron plays an important role in promoting phytohormones and nucleic acids (Khayyat et al., 2007). Among all phytohormones, IAA is the most involved with B nutrition in plants. Many B-deficiency symptoms are similar to the symptoms of low IAA levels in plant; these symptoms include the inhibition of root elongation and lateral root initiation (Pilbeam and Kirkby, 1983). Results in Table 6 show that the higher the BA concentration, either alone or combined with HA, the higher the IAA level in 'Zebda' mango leaves, except for the highest concentrations of HA and BA $(0.45 \% \mathrm{HA}+600$ $\mathrm{mg} \cdot \mathrm{L}^{-1} \mathrm{BA}$ ), which might be related to the inhibition effect of high concentrations of both HA (Chen and Avaid, 1990) and B (Yua and Ryan, 2008). Boron improves the activity of IAA, which enhances carbohydrate transport in plants, especially under stressful conditions (Patrick and Wareing, 1973). Lee et al. (2006) noticed an increase in ABA concentration under $\mathrm{B}$ deficiency. Boron deficiency reduced IAA and increased ABA levels in shoots and roots of rapeseed plants (Zhou et al., 2016). These findings are consistent with results of IAA and ABA shown in Table 6. However, some newer reports indicate that $\mathrm{B}$ deficiency induces the biosynthesis of both IAA and ABA, but decreased $\mathrm{GA}_{3}$ and CKs biosynthesis in shoots of rapeseed seedlings (Eggert and von Wiren, 2017) and olive leaves and buds (Hegazi et al., 2018). These findings have also been confirmed by the results of $\mathrm{GA}_{3}, \mathrm{CKs}$, and $\mathrm{ABA}$ displayed in Table 6. It has also been reported that $\mathrm{N}$ nutrition is important for CKs metabolism (Kiba et al., 2011). As shown in Tables 3 and 6 , treatment with $0.30 \% \mathrm{HA}+600 \mathrm{mg} \cdot \mathrm{L}^{-1}$ BA improved both $\mathrm{N}$ and CKs. Reports have also shown an up-regulation of ABA-related genes under conditions of P (Woo et al., 2012), N, or K deficiency (Oka et al., 2012). Control showed the lowest N-P-K concentrations (Table 3), meanwhile it has the highest ABA content (Table 6). Eggert and von Wiren (2017) reported that reduced water uptake under B deficiency conditions may promote water stress and increase ABA concentration. Under such conditions, the increase in ABA level may adjust shoot growth via the regulation of transpiration and photosynthesis. A balance in IAA, $\mathrm{GA}_{3}$, and ABA levels resulted in the highest fruit set and total yield in 'Frantoio' olive trees (Hegazi et al., 2018).

Floral assessment and total yield. Regardless of the application of $300 \mathrm{mg} \cdot \mathrm{L}^{-1}$ BA during the second season, all single and combined applications of HA and BA were so effective in improving floral development and significantly increased the number of panicles per tree compared with the untreated trees during both seasons (Table 7). Humic acid was also more effective than BA in this regard. Moreover, the percentage of floral malformation was significantly reduced with all treatments, and thus total fruit yield was also increased significantly in both seasons. The best results were achieved with the application of $0.30 \% \mathrm{HA}+600 \mathrm{mg} \cdot \mathrm{L}^{-1} \mathrm{BA}$. Results of both seasons indicated that untreated trees showed $\approx 25 \%$ floral malformation, whereas this percentage was reduced with all treatments to reach a minimum of $14 \%$ in trees received $0.30 \% \mathrm{HA}+600$ $\mathrm{mg} \cdot \mathrm{L}^{-1} \mathrm{BA}$. This was reflected on total fruit yield, which increased and became almost the same (i.e., 43.4 and $43.8 \mathrm{~kg} /$ tree) in both 2017 off-year and 2018 on-year, respectively. Total yield increased by 3.3- and 1.5-fold in comparison with the control during the offyear and on-year, respectively.

Mango malformation is a major constraint in mango production areas (Crane and Campbell, 1994) and has been early reported in Egypt (Attiah, 1955). It could be ascribed to physiological disorders that are related to biotic stress (e.g., acarological, viral or fungal disease Fusarium moniliforme) or abiotic stress (e.g., salinity, drought, oxidative, low temperature, metal toxicity) (Ansari et al., 2015). Several reports related malformation to the increase in endogenous ethylene (Bains and Pant, 2003), which is usually associated with an increase in $\mathrm{ABA}$, and a reduction in IAA, $\mathrm{GA}_{3}$, and CKs (Helaly et al., 2017).
Ansari et al. (2019) noted a higher level of cyanide, as a by-product of ethylene biosynthesis in malformed mango inflorescences. Auxin is important for the production of healthy panicles (Kumar et al., 2011). Results in Table 6 are compatible with previous reports in which the application of $0.30 \%$ $\mathrm{HA}+600 \mathrm{mg} \cdot \mathrm{L}^{-1} \mathrm{BA}$ increased the level of IAA, $\mathrm{GA}_{3}$, and $\mathrm{CKs}$ but decreased ABA level. Meanwhile, the same treatment reduced the malformation percentage and increased the number of healthy panicles per tree, and thus improved total yield (Table 7). In general, cultivars 'Zebda' and 'Hindi' are less susceptible to floral malformation, but 'Ewais' is moderately susceptible (Azzous et al., 1978). Resistance to malformation in 'Zebda' mango has previously confirmed with using the extract of leaves and shoots to inhibit the growth of Fusarium subglutinans fungus in vitro (El-Ghandour et al., 1979). 'Ewais' mango showed the higher values of leaf area, photosynthetic pigments, leaf mineral content, panicle length, sex ratio, fruit retention, and total yield per tree, whereas 'Zebda' mango showed higher attributes of leaf carotene content and resistance to malformation (Zagzog and Gad, 2017). In this respect, it could be mentioned that the growth vigor and susceptibility to malformation of mango cultivars is a genetic-related effect (Bally, 2006), which is also greatly affected with environmental factors that affect growth and development (Zuo et al., 2007). Application of HA and BA has improved overall tree physiology (Tables 2-6) and led to reduced malformation percentage (Table 7).

Results displayed in Tables 3 and 7 confirm previous reports that have described the role of HA in improving nutrient availability, number of flowers per tree, fruit set and retention, and total yield of 'Superior Seedless' grape (Omar and Abdelall, 2005), 'Kinnow' mandarin (Abbas et al., 2013), 'Manfalouty' pomegranate (Khattab et al., 2012), and 'Red Delicious' apple (Hidayatullah et al., 2018). Application of $500 \mathrm{mg} \cdot \mathrm{L}^{-1} \mathrm{HA}$ increased the number of harvested flowers in gerbera plants by $52 \%$ and extended the vase life by 2 to $3.6 \mathrm{~d}$. This effect was mostly due to the auxin component of HA (Arslan and Pehlivan, 2008).

Table 7. Effect of humic acid (HA) and boron [as boric acid (BA)] on the number of panicles, floral malformation, and total yield of 'Zebda' mango trees during 2017 and 2018 seasons.

\begin{tabular}{|c|c|c|c|c|c|c|}
\hline \multirow[b]{2}{*}{ Treatments } & \multicolumn{2}{|c|}{ Number of panicles per tree } & \multicolumn{2}{|c|}{ Floral malformation (\%) } & \multicolumn{2}{|c|}{ Total yield $(\mathrm{kg} /$ tree $)$} \\
\hline & 2017 & 2018 & 2017 & 2018 & 2017 & 2018 \\
\hline $0.15 \%$ HA & 277 & 283 & 21.5 & 22.1 & 35.7 & 36.4 \\
\hline $300 \mathrm{mg} \cdot \mathrm{L}^{-1} \mathrm{BA}$ & 267 & 278 & 21.8 & 21.1 & 36.8 & 37.5 \\
\hline $600 \mathrm{mg} \cdot \mathrm{L}^{-1} \mathrm{BA}$ & 275 & 292 & 20.7 & 20.0 & 37.6 & 38.3 \\
\hline $0.15 \% \mathrm{HA}+300 \mathrm{mg} \cdot \mathrm{L}^{-1} \mathrm{BA}$ & 293 & 307 & 19.3 & 19.0 & 39.4 & 39.8 \\
\hline $0.15 \% \mathrm{HA}+600 \mathrm{mg} \cdot \mathrm{L}^{-1} \mathrm{BA}$ & 314 & 329 & 16.8 & 16.5 & 41.5 & 42.2 \\
\hline $0.30 \% \mathrm{HA}+600 \mathrm{mg} \cdot \mathrm{L}^{-1} \mathrm{BA}$ & 326 & 338 & 14.7 & 14.2 & 43.4 & 43.8 \\
\hline $0.45 \% \mathrm{HA}+600 \mathrm{mg} \cdot \mathrm{L}^{-1} \mathrm{BA}$ & 311 & 321 & 16.7 & 16.3 & 41.2 & 41.7 \\
\hline Least significant difference $(P \leq 0.05)$ & 11.41 & 10.76 & 0.31 & 0.28 & 1.12 & 1.01 \\
\hline
\end{tabular}


Previous findings indicated that annual spray of 'Tommy Atkins' mango trees with micronutrients (e.g., $\mathrm{Zn}, \mathrm{Fe}, \mathrm{B}, \mathrm{Cu}$, and $\mathrm{Mn}$ ) in combination with $\mathrm{HA}$ resulted in healthy mango trees with a lower percentage of malformation, increased fruit retention and tree productivity, and improved fruit physiochemical characteristics (Mouco at al., 2009).

Foliar B application improved panicle growth, fruit retention and physicochemical characteristics of 'Himsagar' mango (Dutta, 2004). The key role of B includes floral organ development, male flower fertility, and pollen tube growth (Gupta and Solanki, 2013; Saini et al., 2019). Boron deficiency during flowering period may cause severe yield loss through sterility (Uraguchi and Fujiwara, 2011), low pollen viability, poor pollen germination, or reduced pollen tube growth (Baldi et al., 2004); therefore, B has a vital role in fruit set (Acar et al., 2010). Boron is rapidly absorbed by flowers (Sarrwy et al., 2012) and improves carbohydrate transport affecting fruit set and development (Mengel and Kirkby, 2001). The beneficial effect of B on decreasing malformation percentage may be due to its role in inducing the formation of a Si-cuticle double layer on leaf epidermal tissues, which is responsible for preventing the penetration of fungal hyphae (Baiea et al., 2015). Increases in fruit yield with B application have been reported in 'Conference' pear (Wojcik and Wojcik, 2003), stone fruits (Baldi et al., 2004), and 'Shahany' date palm
(Khayyat et al., 2007). Increases in fruit yield with the application of $\mathrm{B}$ and $\mathrm{Zn}$ was reported in 'Chausa' mango (Singh and Rajput, 1976) and three cultivars of sweet cherry (Usenik and Stampar, 2002). The application of Zn, either alone or in combination with $\mathrm{B}$ increased the number of fruit in 'Feutrell's Early' mandarin trees by $17 \%$ and $21 \%$, respectively, proving the role of $\mathrm{B}$ vitalizing $\mathrm{Zn}$ effect (Khan et al., 2012). The highest yield of 'Taimour', 'Mabrouka', and 'Alphonso' mango trees was observed with the annual single or combined application of $\mathrm{B}, \mathrm{Cu}$, and naphthalene acetic acid (NAA) (Shinde et al., 2006). Application of B and Zn improves the biochemistry of flowers and enhanced $\mathrm{N}-\mathrm{P}-\mathrm{K}$ uptake, fruit set and retention, total yield, and fruit quality; in terms of fruit weight, TSS, acidity, pulp recovery, and sugar concentration (Alloway, 2009). The effect was more pronounced with B rather than $\mathrm{Zn}$ (Davarpanah et al., 2016). It is also suggested to be season-specific effect and does not extend to the next season.

Fruit physiochemical characteristics. Like all other studied parameters, foliar spray of 'Zebda' mango trees with $0.30 \% \mathrm{HA}+600$ $\mathrm{mg} \cdot \mathrm{L}^{-1} \mathrm{BA}$ has also reflected on fruit physical and chemical characteristics (Tables 8 and 9) due to the improvement in leaf area, photosynthetic pigments (Table 2), nutrient uptake (Table 3), carbon assimilation (Tables 4 and 5), and phytohormones, particularly IAA, $\mathrm{GA}_{3}$, and CKs (Table 6). These results are in consistence with the previous findings on 'Anna' apple (Khalifa et al., 2009), 'Kesar' mango (Ngullie et al., 2014), and 'Frantoio' olive (Hegazi et al., 2018). Application of HA and B significantly increased total sugars of 'Alphonso' mango fruit (Merwad et al., 2016). The increase in sugar content could be due to the role of $\mathrm{B}$ on sugar translocation from leaves (source) to developing fruit (sink). This could also be referred to HA hormone-like effect on plant growth, yield, and fruit quality (Calvo et al., 2014).

Humic acid hormone-like effect, particularly IAA, has been documented on total yield, fruit weight, dimensions, TSS, acidity, and sugar content in 'Italia' table grape (Giuseppe et al., 2005); 'Keitt', 'Ewais', and 'Kesar' mango (El-Kosary et al., 2011; Ngullie et al., 2014); 'Florida Prince' peach (Abd El-Razek et al., 2012); and 'Kalamata' olive (Hagagg et al., 2013). Humic acid at 1\% recorded maximum custard apple fruit yield per plant, fruit weight and diameter, TSS, total sugars, reducing and nonreducing sugars, ascorbic acid, and extended shelf life, whereas no effect on acidity has been noticed (Sindha et al., 2018). The increase in 'Askari' grape shelf life may be related to the role of HA in stimulating enzyme activity and firmness of cell walls (Mohamadineia et al., 2015). The increase in fruit weight and TSS may be due to the stimulation of photosynthetic pigment accumulation, photosynthesis rate (Abdel-Mawgoud et al., 2007), N uptake,

Table 8. Effect of humic acid (HA) and boron [as boric acid (BA)] on some fruit physical characteristics of 'Zebda' mango during 2017 and 2018 seasons.

\begin{tabular}{|c|c|c|c|c|c|c|c|c|}
\hline \multirow[b]{2}{*}{ Treatments } & \multicolumn{2}{|c|}{ Fruit wt (g) } & \multicolumn{2}{|c|}{ Fruit length (mm) } & \multicolumn{2}{|c|}{ Fruit width $(\mathrm{mm})$} & \multicolumn{2}{|c|}{ Pulp wt (g) } \\
\hline & 2017 & 2018 & 2017 & 2018 & 2017 & 2018 & 2017 & 2018 \\
\hline$\overline{\text { Control }}$ & 457 & 442 & 112.4 & 112.7 & 62.3 & 63.4 & 268.6 & 274.3 \\
\hline $0.15 \%$ HA & 468 & 471 & 123.6 & 124.3 & 65.4 & 66.5 & 284.5 & 287.2 \\
\hline $0.30 \% \mathrm{HA}$ & 482 & 488 & 127.2 & 127.8 & 68.8 & 68.8 & 292.4 & 297.5 \\
\hline $0.45 \%$ HA & 502 & 495 & 129.2 & 129.8 & 69.6 & 70.4 & 296.8 & 299.4 \\
\hline $300 \mathrm{mg} \cdot \mathrm{L}^{-1} \mathrm{BA}$ & 482 & 481 & 126.2 & 128.7 & 67.6 & 68.2 & 285.8 & 291.6 \\
\hline $600 \mathrm{mg} \cdot \mathrm{L}^{-1} \mathrm{BA}$ & 498 & 484 & 127.3 & 129.4 & 68.5 & 69.2 & 287.9 & 297.4 \\
\hline $0.15 \% \mathrm{HA}+300 \mathrm{mg} \cdot \mathrm{L}^{-1} \mathrm{BA}$ & 482 & 497 & 132.1 & 133.2 & 70.2 & 70.7 & 298.4 & 301.5 \\
\hline $0.30 \% \mathrm{HA}+300 \mathrm{mg} \cdot \mathrm{L}^{-1} \mathrm{BA}$ & 497 & 501 & 135.3 & 135.7 & 71.3 & 72.0 & 302.6 & 304.3 \\
\hline $0.45 \% \mathrm{HA}+300 \mathrm{mg} \cdot \mathrm{L}^{-1} \mathrm{BA}$ & 501 & 503 & 136.2 & 137.2 & 71.8 & 72.5 & 304.2 & 235.4 \\
\hline $0.15 \% \mathrm{HA}+600 \mathrm{mg} \cdot \mathrm{L}^{-1} \mathrm{BA}$ & 504 & 508 & 137.7 & 137.2 & 72.4 & 73.2 & 308.3 & 309.7 \\
\hline $0.30 \% \mathrm{HA}+600 \mathrm{mg} \cdot \mathrm{L}^{-1} \mathrm{BA}$ & 511 & 514 & 138.2 & 138.7 & 75.7 & 76.4 & 316.4 & 318.3 \\
\hline $0.45 \% \mathrm{HA}+600 \mathrm{mg} \cdot \mathrm{L}^{-1} \mathrm{BA}$ & 498 & 502 & 134.2 & 135.6 & 71.6 & 72.3 & 305.7 & 306.4 \\
\hline Least significant difference $(P \leq 0.05)$ & 11.66 & 10.33 & 4.11 & 4.33 & 1.21 & 1.30 & 2.99 & 6.33 \\
\hline
\end{tabular}

Table 9. Effect of humic acid (HA) and boron [as boric acid (BA)] on the percentage of total soluble solids (TSS), total acidity, and total sugars of 'Zebda' mango fruit during 2017 and 2018 seasons.

\begin{tabular}{|c|c|c|c|c|c|c|}
\hline \multirow[b]{2}{*}{ Treatments } & \multicolumn{2}{|c|}{ TSS (\%) } & \multicolumn{2}{|c|}{ Total acidity $(\%)$} & \multicolumn{2}{|c|}{ Total sugars $(\%)$} \\
\hline & 2017 & 2018 & 2017 & 2018 & 2017 & 2018 \\
\hline $0.15 \% \mathrm{HA}$ & 21.3 & 21.4 & 0.21 & 0.22 & 17.4 & 17.8 \\
\hline $300 \mathrm{mg} \cdot \mathrm{L}^{-1} \mathrm{BA}$ & 21.3 & 21.5 & 0.21 & 0.21 & 17.6 & 18.1 \\
\hline $600 \mathrm{mg} \cdot \mathrm{L}^{-1} \mathrm{BA}$ & 21.6 & 21.7 & 0.21 & 0.20 & 17.9 & 18.3 \\
\hline $0.15 \% \mathrm{HA}+300 \mathrm{mg} \cdot \mathrm{L}^{-1} \mathrm{BA}$ & 22.4 & 22.7 & 0.19 & 0.18 & 18.4 & 18.7 \\
\hline $0.15 \% \mathrm{HA}+600 \mathrm{mg} \cdot \mathrm{L}^{-1} \mathrm{BA}$ & 23.1 & 23.2 & 0.17 & 0.16 & 19.5 & 19.8 \\
\hline $0.30 \% \mathrm{HA}+600 \mathrm{mg} \cdot \mathrm{L}^{-1} \mathrm{BA}$ & 23.6 & 24.7 & 0.15 & 0.15 & 20.3 & 20.5 \\
\hline $0.45 \% \mathrm{HA}+600 \mathrm{mg} \cdot \mathrm{L}^{-1} \mathrm{BA}$ & 22.5 & 23.1 & 0.17 & 0.16 & 19.7 & 19.8 \\
\hline Least significant difference $(P \leq 0.05)$ & 0.62 & 0.59 & 0.03 & 0.05 & 0.01 & 0.97 \\
\hline
\end{tabular}


assimilation ratio, and phytohormone activity (Patrick and Wareing, 1973). The increase in total sugars with HA application might be due to the increase in carbohydrate accumulation in leaf and fruit tissues, which ultimately converted to glucose and sucrose, as well as the breakdown of starch into sugars during ripening (Hermans et al., 2006).

Application of B increases fruit set, yield, and fruit quality of 'Butte' almond (Nyomora and Brown, 1999) and 'Manzanillo' olive (Perica et al., 2001). It was reported that application of $\mathrm{Zn}$ and $\mathrm{B}$ increased stomatal number per leaf, and enhanced $\mathrm{CO}_{2}$ inflow into the mesophyll tissue resulting in more photosynthates, which increased fruit yield and quality of Brazilian cashew (Aliyu et al., 2011). Combined application of $\mathrm{Zn}$ and $\mathrm{B}$ led to increase in 'Ardestani' pomegranate fruit maturity index (TSS:acid ratio), whereas physical fruit characteristics were unaffected (Davarpanah et al., 2016). Foliar B application improved fruit physicochemical characteristics of 'Himsagr' (Dutta, 2004) and 'Chaunsa' mango (Ahmad et al., 2018). Boron (1\%) improved TSS of 'Amrapali' mango fruit (Umesh et al., 2010). Single or combined foliar application of $\mathrm{Zn}, \mathrm{Fe}, \mathrm{Mn}, \mathrm{B}$, or $\mathrm{Cu}$ increased total sugar content in 'Dashehari', 'Hindi', 'Taimour', 'Mabrouka', 'Himsagar', 'Langra', and 'Amrapali' mango fruit (Hammam et al., 2001; Rashmi et al., 2007; Vejendla et al., 2008). Boron plays a major role in stabilizing pectin fraction in cell walls, thereby improving fruit firmness and maintaining fruit quality (Goldbach and Wimmer, 2007).

In summary, flowering in mango is a complex physiological process that determines annual fruit production (Davenport, 2007). Mango has high fruiting potential with a tendency of alternate bearing (Saker and Rahim, 2013). Most of the Egyptian mango cultivars, particularly Zebda, suffer from alternate bearing (Shaban, 2009a). As shown in Table 7 , the number of panicles and total yield per tree during the off-year were $\approx 57.7 \%$ and $45 \%$, respectively compared with the on-year. Complex interactions between shoot development and environmental conditions resulted in floral bud initiation in mango. This process occurs before the onset of the coolest months of the year, which is the period from December to January in Egypt, and is generally influenced by previous crop load (Shaban, 2009b), bearing habit, genetic characteristics (Smith-Ramirez et al., 1998), age and size of reproductive shoots, and other plant factors (Ramirez and Davenport, 2012). Climatic factors and environmental stresses are also associated with alternate bearing of mango trees in two ways: either by damaging the crop directly through destroying buds, flowers, and fruits or by creating conditions that indirectly affect the production of flower or fruit. The optimal temperature for plant growth and flowering is $\approx 24$ to $30{ }^{\circ} \mathrm{C}$; however, mango trees can tolerate temperatures up to $48^{\circ} \mathrm{C}$ for short periods and are sensitive to temperature below $10{ }^{\circ} \mathrm{C}$ (Whily et al., 1989). Early spring frost, photoperiod,

Table 10. Total yield of untreated 'Zebda' mango trees during 5 years, associated with average weather data per year calculated from September to August of each growth season. Yield least significant difference $=8.6(P \leq 0.05)$.

\begin{tabular}{lccccc}
\hline Season & $2014-15$ & $2015-16$ & $2016-17$ & $2017-18$ & $2018-19$ \\
\hline Yield (kg/tree) & 9.9 & 25.5 & 13.2 & 29.3 & 11.0 \\
Alternate bearing & Off & On & Off & On & Off \\
Temperature $\left({ }^{\circ} \mathrm{C}\right)$ & 21.8 & 22.5 & 21.5 & 23.0 & 26.8 \\
Humidity $(\%)$ & 54.0 & 54.9 & 55.7 & 52.2 & 52.7 \\
Cloud (\%) & 12.8 & 15.3 & 14.4 & 14.3 & 15.3 \\
Rainfall (millimeters/month) & 0.4 & 0.8 & 0.6 & 0.4 & 5.2 \\
Rainfall (days/month) & 1.2 & 1.6 & 0.8 & 0.8 & 4.3 \\
Wind speed (kilometers/hour) & 8.2 & 7.9 & 8.2 & 11.9 & 13.1 \\
Gust speed (kilometers/hour) & 11.0 & 10.7 & 11.0 & 16.0 & 18.0 \\
Sun (hours/month) & 299.6 & 296.8 & 300.0 & 293.8 & 291.8 \\
Sun (days/month) & 29.5 & 28.8 & 29.1 & 29.3 & 26.0 \\
\hline
\end{tabular}

cloudy weather, and rains during flowering period reduce the crop and could convert an on-year into an off-year (Davenport, 2009). However, mango is highly heterozygous tree; mean genotype $\times$ environment interaction is high, and hence, it is stable enough to perform under different climatic conditions of tropical, subtropical, or temperate zones (Eiadthong et al., 2000). In addition, the increase in carbohydrate availability is required for high $\mathrm{C} / \mathrm{N}$ ratio, which is an important attribute for floral initiation in mango (Upreti et al., 2013). This ratio also differs with the environmental conditions and prevailing metabolic balance. The increase in carbohydrates is concomitant with changes in phytohormones, especially with the decline in gibberellin level (Sandip et al., 2015). Humic acid and B play an important role in hormonal balance (Canellas et al., 2015; Zhou et al., 2016). It should be noted that even in the regular-bearing tree fruit types, if they produce high yield in one year, they show a tendency toward reduced yield the following year. Hence, the basic tendency of alternate bearing exists even in the "regularbearing" varieties of mango. In other words, the potential of shoot to form flower buds will depend on the nutritional condition of the tree, which in turn will be determined by the amount of fruit load carried by the tree in the previous year. Generally, moderate flowering is one of the major conditions of annual fruit bearing in fruit trees. Therefore, the fruit development depends on the current year assimilates, and to a great extent on the tree reserve. The use of reserve metabolites from vegetative organs during the on-year could contribute to alternate bearing (Singh, 1971). In the present study, we suggest that alternate bearing of 'Zebda' mango trees was mainly dependent on annual tree reserve and metabolite availability, and to a lesser extent on weather conditions, which were almost the same in both seasons and hence have minimal effect on the incidence of alternate bearing under the Egyptian conditions. This is also confirmed with the 5 -years yield and weather data (World Weather Online, 2020) (Table 10). However, the tendency to alternate bearing has been improved in 2017 off-year with the application of HA and BA (Table 7). Therefore, results of this study confirmed the significance role of HA and BA improving plant nutritional status, growth, and annual productivity.

\section{Conclusion}

Humic acid and B exert direct and indirect effects on plant morphological, physiological, biochemical, and genetic processes, which ultimately affect plant growth, yield, and fruit quality. The tremendous effect of $0.30 \% \mathrm{HA}+600 \mathrm{mg} \cdot \mathrm{L}^{-1} \mathrm{BA}$ on nutrient uptake, carbon assimilation and metabolism, and phytohormone activity may indicate a possibility of tree tolerance to adverse conditions that cause floral malformation and reduce productivity. Moreover, the stability and increased consistency of tree productivity from one season to another in response to $\mathrm{HA}$ and $\mathrm{B}$ are a promising tool to minimize the incidence of alternate bearing and improve mango tree growth, annual productivity, and fruit quality.

\section{Literature Cited}

Association of Official Analytical Chemists. 1990. Official methods of analysis. Vol. 1. 15th ed. K. Helrich (ed.). A.O.A.C. Inc., Arlington, VA. $<$ https://law.resource.org/pub/us/cfr/ibr/002/ aoac.methods.1.1990.pdf $>$.

Abbas, T., S. Ahmad, M. Ashraf, M. Adnan, M. Yasin, and R.M. Balal. 2013. Effect of humic and application at different growth stages of Kinnow mandarin (Citrus reticulate Blanco) on the basis of physio-biochemical and reproductive responses. Acad. J. Biotech. 1:14-20.

Abd El-Razek, E., A. Abd-allah, and M. Saleh. 2012. Yield and fruit quality of Florida prince peach trees as affected by foliar and soil applications of humic acid. J. Appl. Sci. Res. 8:5724-5729. < https://pdfs.semanticscholar.org/ 5da6/bec04c65396614bbcae4e549dd963c0f0721. pdf $>$.

Abdel-Mawgoud, A.M.R., N. El-Greadly, Y.I. Helmy, and S.M. Singer. 2007. Response of tomato plants to different rates of humic based fertilizer and NPK fertilization. J. Appl. Sci. Res. 3:169-174. <https://www.researchgate.net/ publication/317339366-tomato-Growplex.pdf>.

Acar, I., B.E. Ak, and K. Sarpkaya. 2010. Effects of boron and gibberellic acid on in vitro pollen germination of pistachio (Pistacia vera $\mathrm{L}$.). Afr. J. Biotechnol. 9:5126-5130.

Ackerson, R.C. and R.D. Krieg. 1977. Stomatal and nonstomatal regulation of water-use in cotton, corn and sorghum. Plant Physiol. 60: $850-853$. 
Ahmad, I., F. Bibin, H. Ullahn, and T.M. Muninr. 2018. Mango fruit yield and critical quality parameters respond to foliar and soil applications of zinc and boron. Plants 7:97.

Ahmed, F.F. and M.H. Morsy. 1999. A new method for measuring leaf area in different fruit species. Minia J. Agr. Res. Develop. 19:97-105.

Ali, M.S., M.A. Elhamahmy, and A.F. El-Sheikh. 2017. Mango trees productivity and quality as affected by boron and putrescine. Scientia Hort. 216:248-255.

Aliyu, O.M., O.O. Adeigbe, and J.A. Awopetu. 2011. Foliar application of the exogenous plant hormones at preblooming stage improves flowering and fruiting in cashew (Anacardium occidentale L.). J. Crop Sci. Biotechnol. 14: 143-150.

Alloway, B. 2009. Soil factors associated with zinc deficiency in crops and humans. Environ. Geochem. Health 31:537-548.

Anees, M., F.M. Tahir, J. Shahzad, and N. Mahmood. 2011. Effect of foliar application of micronutrients on the quality of mango (Mangifera indica L.) cv. Dusehrifruit. Mycopath 9:25-28. <https://pdfs.semanticscholar.org/d7d6/ 12cf787507471f28d596b41c913fb168f619.pdf >.

Ansari, M.W., S. Kaushik, G. Bains, S. Tula, B. Joshi, V. Rani, R.K. Wattal, R. Rakwal, A. Shukla, R.C. Pant, R. Tuteja, and N. Tuteja. 2019. Cyanide produced with ethylene by ACS and its incomplete detoxification by $\beta$-CAS in mango inflorescence leads to malformation. Sci. Rep. 9:18361.

Ansari, M.W., V. Rani, A. Shukla, G. Bains, R.C. Pant, and N. Tuteja. 2015. Mango (Mangifera indica L.) malformation: A malady of stress ethylene origin. Physiol. Mol. Biol. Plants $21: 1-8$.

Arslan, G. and E. Pehlivan. 2008. Uptake of $\mathrm{Cr}^{3+}$ from aqueous solution by lignite-based humic acids. Bioresour. Technol. 99:597-605.

Aslam, M., B. Sultana, F. Anwar, and H. Munir. 2016. Foliar spray of selected plant growth regulators affected the biochemical and antioxidant attributes of spinach in a field experiment. Turk. J. Agr. 40:136-145.

Attiah, H.H. 1955. A new eriophyid mite on mango from Egypt. Bull. Soc. Ent. Egypt. 39:379-383.

Aydin, A., C. Kant, and M. Turan. 2012. Humic acid application alleviate salinity stress of bean (Phaseolus vulgaris L.) plants decreasing membrane leakage. Afr. J. Agr. Res. 7:1073-1086.

Azzous, S., Z.M. Hamdy, and I.M. Dahshan. 1978. Studies on malformed inflorescence of mango, the degree of susceptibility among different varieties. Agr. Res. Rev. 56:17-27.

Babu, K.D. and D.S. Yadav. 2005. Foliar spray of micronutrients for yield and quality improvement in Khasi mandarin (Citrus reticulata Blanco). Intl. J. Hort. 62:280-281.

Baiea, M.M., H.E.M. El-Badawy, and S.F. ElGioushy. 2015. Effect of potassium, zinc and boron on growth, yield and fruit quality of keitt mango trees. Res. J. Pharm. Bio. Chem. 6:800812. <https://www.researchgate.net/publication/ 283150993_117.pdf>.

Bains, G. and R.C. Pant. 2003. Mango malformation: Etiology and preventive measures. Physiol. Mol. Biol. Plants 9:41-61. <https://www. researchgate.net/publication/288085619>.

Balasundram, N., K. Sundram, and S. Samman. 2006. Phenolic compounds in plants and agriindustrial by-products: Antioxidant activity, occurrence, and potential uses. Food Chem. 99:191-203.

Baldi, E., M. Toselli, D. Deudellar, M. Tagliavini, and B. Marangoni. 2004. Foliar feeding of stone fruit trees. Inf. Agrar. 60:43-46.
Bally, I.S.E. 2006. Mangifera indica (mango), ver. 3.1, p. 1-25. In: C.R. Elevitch (ed.). Species profiles for Pacific island Agroforestry. Permanent Agriculture Resources (PAR), Holualoa, HI. 12 May 2020. <https://www.academia.edu/ 28042629/Mangifera_indica_mango_-_Agroforestry.net>.

Bates, L.S., R.P. Waldern, and I.D. Teara. 1973. Rapid determination of free proline for water stress studies. Plant Soil 39:205-207.

Boehme, M., J. Schevtschenko, and I. Pinker. 2005. Iron supply of cucumbers in substrate culture with humate. Acta Hort. (41:329-335. <https:// wwwlib.teiep.gr/images/stories/acta/Acta\%20697/ 697_41.pdf $>$.

Bonilla, I., A. El-Hamdaoui, and L. Bolaños. 2004. Boron and calcium increase Pisum sativum seed germination and seedling development under salt stress. Plant Soil 267:97-107.

Botta, A. 2013. Enhancing plant tolerance to temperature stress with amino acids: An approach to their mode of action. Acta Hort. (1009: 29-35.

Boud, A. 2007. Evolution and current status of research in phenolic compounds. Phytochemistry 68:2722-2735.

Bould, C., E.J. Hewitt, and P. Needham. 1983. Diagnosis of mineral disorders in plants. Vol. 1. Principles. Her Majesty's Stationery Office Publisher, London, UK. <https://www.cabdirect. org/cabdirect/abstract/19841987465>.

Bulgari, R., G. Franzoni, and A. Ferrante. 2019. Biostimulants application in horticultural crops under abiotic stress conditions. Agronomy 9:306.

Calvo, P., L. Nelson, and J.W. Kloeppe. 2014. Agricultural uses of plant biostimulants. Plant Soil. 383:3-41.

Camacho-Cristóbal, J.J., E.M. Martín-Rejano, M.B. Herrera-Rodríguez, M.T. Navarro-Gochicoa, J. Rexach, and A. González-Fontes. 2015. Boron deficiency inhibits root cell elongation via an ethylene/auxin/ROS-dependent pathway in Arabidopsis seedlings. J. Expt. Bot. 66: 3831-3840.

Can, W., M. Kafi, M. Babalar, and Y. Xia. 2008. Effect of humic acid on plant growth, nutrient uptake, and postharvest life of gerbera. J. Plant Nutr. 31:2155-2167.

Canellas, L.P. and F.L. Olivares. 2014. Physiological responses to humic substances as plant growth promoter. Chem. Biol Techn. Agri. 1:3.

Canellas, L.P., F.L. Olivares, N.O. Aguiar, D.L. Jones, A. Nebbioso, P. Mazzei, and A. Piccolo. 2015. Humic and fulvic acids as biostimulants in horticulture. Scientia Hort. 196:15-27.

Carletti, P., A. Masi, B. Spolaore, P.P. De Laureto, M. De Zorz, L. Turetta, M. Ferretti, and S. Nardi. 2008. Protein expression changes in maize roots in response to humic substances. J. Chem. Ecol. 34:804-818.

Chadha, K.L. 1993. Fruit drop in mango, p. 11311166. In: K.L. Chadha and O.P. Pareek (eds.). Advances in horticulture, Vol. 3. Malhotra Publishing House, New Delhi, India.

Chen, Y., M. De Nobili, and T. Aviad. 2004. Stimulatory effects of humic substances on plant growth, p. 103-129. In: F.R. Magdoff and R.R. Weil (eds.). Soil organic matter in sustainable agriculture. 1st ed. CRC Press, Boca Raton, FL. <http://www.crcpress.com/ Magdoff-Weil/p/book/9780367394233>.

Chen, Y. and T. Avaid. 1990. Effect of humic substances on plant growth, p. 161-186. In: P. MacCarthy, C.E. Clapp, R.L.P. Malcolm, and R. Bloom (eds.). American Society of Agronomy, Madison, WI.

Cimrin, K.M., O. Turkmen, M. Turan, and B. Tuncer. 2010. Phosphorus and humic acid ap- plication alleviate salinity stress of pepper seedlings. Afr. J. Biotechnol. 9:5845-5851.

Colla, G., S. Nardi, M. Cardarelli, A. Ertani, L. Lucini, and R. Canaguier. 2015. Protein hydrolysates as biostimulants in horticulture. Scientia Hort. 30:28-38.

Crane, J.H. and C.W. Campbell. 1994. The mango, p. 24. The horticultural science department, Florida Co-operative Extension Service, Institute Food and Agri Science, University of Florida. <https://aggie-horticulture.tamu.edu/ syllabi/423/MangoFlorida.pdf>.

Cuin, T.A. and S. Shabala. 2007. Amino acids regulate salinity-induced potassium efflux in barley root epidermis. Planta 225:753-761.

Dabbaghi, O., M. Tekaya, S. Öden, T. Willems, F. Attia, M. Hammami, E. Prinsen, and B. Mechri. 2018. Foliar application of biofertilizers influenced the endogenous concentrations of phytohormones and amino acids in leaves and roots of olive trees (Olea europaea L. cv. Chemlali). Afr. J. Agr. Res. 13:17771786.

Davarpanah, S., A. Tehranifar, G. Davarynejad, J. Abadía, and R. Khorasani. 2016. Effects of foliar applications of zinc and boron nanofertilisers on pomegranate (Punica granatum cv. Ardestani) fruit yield and quality. Scientia Hort. 210:57-64.

Davenport, T.L. 2007. Reproductive physiology of mango. Braz. J. Plant Physiol. 19(4):363-376.

Davenport, T.L. 2009. Reproductive physiology, p. 97-169. In: R.E. Litz (ed.). The mango botany production and uses. 2nd ed. CAB Intl. Wallingford, UK.

Demir, K., A. Günes, A. Inal, and M. Alpaslan. 1999. Effects of humic acids on the yield and mineral nutrition of cucumber (Cucumis sativus, L.) grown with different salinity levels. Acta Hort. (492:95-104.

Dixon, R.A. and N.L. Paiva. 1995. Stress-induced phenylpropanoid metabolism. Plant Cell 7: 1085-1097.

Dobbss, L.B., L.P. Canellas, F.L. Olivares, N.O. Aguiar, L.E.P. Peres, M. Azevedo, R. Spaccini, A. Piccolo, and A.R. Façanha. 2010. Bioactivity of chemically transformed humic matter from vermicompost on plant root growth. J. Agr. Food Chem. 58:3681-3688.

Dubois, M., F. Smith, K.A. Gilles, J.K. Hamilton, and P.A. Robers. 1956. Colorimmetric method for determination of sugars and related substances. Anal. Chem. 28:350-356.

Dutta, P. 2004. Effect of foliar boron application on panicle growth, fruit retention and physicochemical characters of mango cv. Himsagar. Indian J. Hort. 61:265-266.

Eggert, K. and N. von Wiren. 2017. Response of the plant hormone network to boron deficiency. New Phytol. 216:868-881.

Eiadthong, W., K. Yonemori, S. Kansaki, A. Sugiura, N. Utsunomiya, and S. Subhadrabandhu. 2000. Amplified fragments length polymorphism among Mangifera species in Thailand. J. Amer. Soc. Hort. Sci. 125:160-164.

Ekin, Z. 2019. Integrated use of humic acid and plant growth promoting rhizobacteria to ensure higher potato productivity in sustainable agriculture. Sustainability 11:3417.

El-Ghamry, A.M., K.M. Abd El-Hai, and K.M. Ghoneem. 2009. Amino and humic acids promote growth, yield and disease resistance of faba bean cultivated in clayey soil. Aust. J. Basic Appl. Sci. 3:731-739. <https://www. cabdirect.org/cabdirect/abstract/20093184058>.

El-Ghandour, M.A., A.S. Khader, and S.A. Hussein. 1979. Some biological, biochemical and nutritional changes in mango tissues in relation with 
infection with Fusarium moniliforme Sheld. Egypt. J. Hort. 6:13-22.

El-Kosary, S., I.E. El-Shenawy, and S.I. Radwan. 2011. Effect of microelements, amino and humic acids on growth, flowering and fruiting of some mango cultivars. J. Hort. Sci. Ornam. Plants 3:152-161.

Elkhishen, M.A. 2015. Enhancing flowering and fruiting attributes of mango (Mangifera indica) cv. zebda in the off-year by binary application of $\mathrm{KNO}_{3}$, ethrel and paclobutrazol. J. Hortic. Sci. Ornam. Plants 7:87-93.

El-Motaium, R.A., A.E.A. Shaban, S.H. Badawy, and S.A. Ibrahim. 2019. Alleviation of alternate bearing phenomenon in mango (Mangifera indica $\mathrm{L}$.) trees using boron and nitrogen fertilization. J. Plant Nutr. 42(20):2861-2872.

Elsheery, N.I., M.N. Helaly, H.M. El-Hoseiny, and S.M. Alam-Eldein. 2020. Zinc oxide and silicone nanoparticles toimprove the resisitance mechanism and annual productivity of saltstressed mango trees. Agronomy 10(4):558.

Fadeel, A.A. 1962. Location and properties of chloroplasts and pigment determination in roots. Physiol. Plant. 15(1):130-146.

Food and Agriculture Organization of the United Nation. 2020. FAO Statistics. 1 Apr. 2020. $<$ http://www.fao.org/faostat/en/\#data/QC $>$.

Farahat, A.A., A.A. Alsayed, H.S. El-Beltagi, and N.M. Mahfoud. 2012. Impact of organic and inorganic fertilizers on nematode reproduction and biochemical alterations on tomato. Not. Sci. Biol. 4(1):48-55. <https://pdfs.semanticscholar.org/e04f/ d9c6a025a5922f711570cc2009c0f8120323.pdfs.

Gaines, I. and A. Yilmaz. 1983. Comparison of five humic acids. Fuel 62:373-379.

Gao, X., C. Zou, L. Wang, and F. Zhang. 2006. Silicon decreases transpiration rate and conductance from stomata of maize plants. J. Plant Nutr. 29:1637-1647.

Giuseppe, F., P. Andrea, and S. Pasquale. 2005. Preliminary study on the effects of foliar applications of humic acids on 'Italia' table grape. Dipartimento di Scienze delle Produzioni vegetali, University of Bari. <http:// maxgreenproducts.com/wp-content/uploads/ 2016/01/TableGrapeHumicStudy.pdf $>$.

Goldbach, H.E. and M.A. Wimmer. 2007. Boron in plants and animals: Is there a role beyond cellwall structure. J. Plant Nutr. Soil Sci. 170:39-48.

Gupta, U. and H. Solanki. 2013. Impact of boron deficiency on plant growth. Intl. J. Bioassays. 2:1048-1050.

Hagagg, L.F., M.F.M. Shahin, N.S. Mustafa, M.A. Merwad, and F.H. Khalil. 2013. Influence of using humic acid during full bloom and fruit set stages on productivity and fruit quality of 'Kalamata' olive trees. J. Appl. Sci. Res. 9: 2287-2292. <https://pdfs.semanticscholar.org/ 8a32/753216d782cced24e158470fe77f29b25ea1. pdf $>$.

Hager, A. 2003. Role of the plasma membrane $\mathrm{H}+$-ATPase in auxin-induced elongation growth: Historical and new aspects. J. Plant Res. 116:483-505.

Haghighi, M., M. Kafi, and P. Fang. 2012. Photosynthetic activity and $\mathrm{N}$ metabolism of lettuce as affected by humic acid. Intl. J. Veg. Sci. 18: 182-189.

Hammam, M.S., A.M.T. Sabour, and E. Sanaa. 2001. Trials for alleviating inflorescence malformation in Taimour and Mabrouka mango trees. Annals of Agr. Sci. Cairo. 46:753-766.

Han, S., L.S. Chen, H.X. Jiang, B.R. Smith, L.T. Yang, and C.Y. Xie. 2008. Boron deficiency decreases growth and photosynthesis and increases starch and hexoses in leaves of citrus seedlings. J. Plant Physiol. 165:1331-1341.
Hanafy, A., E.M. Harb, M.A. Higazy, and S.H. Morgan. 2008. Effect of silicon and boron foliar applications on wheat plants grown under saline soil conditions. Intl. J. Agr. Res. $3: 1-26$.

Hansch, R. and R. Mendel. 2009. Physiological functions of mineral micronutrients $(\mathrm{Cu}, \mathrm{Zn}$, $\mathrm{Mn}, \mathrm{Fe}, \mathrm{Ni}, \mathrm{Mo}, \mathrm{B}, \mathrm{Cl})$. Curr. Opin. Plant Biol. 12:259-266.

Hassanein, R.A., S.A. El Khawas, H.S. Khafaga, A.S. Abd El-Nabe, and A.S. Abd Elrady. 2017. Amelioration of drought stress on physiological performance of pearl millet (Pennisetum americanum) plant grown under saline condition using potassium humate and silicon source. Egypt J. Exp. Biol. 13:57-68.

Hegazi, E.S., R.A. El-Motaium, T.A. Yehia, and M.E. Hashem. 2018. Effect of foliar boron application on boron, chlorophyll, phenol, sugars and hormones concentration of olive (Olea europea L.) buds, leaves, and fruits. J. Plant Nutr. 41:749-765.

Helaly, M.N., H.A. El-Hoseiny, N.I. El-Sheery, A. Rastogi, and H.M. Kalaji. 2017. Regulation and physiological role of silicon in alleviating drought stress of mango. Plant Physiol. Biochem. 118:31-44.

Helaly, M.N., H.A. El-Hosieny, N.I. Elsheery, and H.M. Kalaji. 2016. Effect of biofertilizers and putrescine amine on the physiological features and productivity of date palm (Phoenix dactylifera, L.) grown on reclaimed-salinized soil. Trees 30:1149-1161.

Helaly, M.N., N.I. El-Sheery, H. El-Hoseiny, A. Rastogi, and H.M. Kalaji. 2018. Impact of treated wastewater and salicylic acid on physiological performance, malformation and yield of two mango cultivars. Scientia Hort. 233: 159-177.

Hermans, C., J.P. Hammond, P.J. White, and N. Verbruggen. 2006. How do plants respond to nutrient shortage by biomass allocation? Trends Plant Sci. 11:610-617.

Hidayatullah, K.A., M.N. Mouladad, and S.A. Shah. 2018. Effect of humic acid on fruit yield attributes, yield and leaf nutrient accumulation of apple trees under calcareous soil. Ind. J. Sci. Techn. 11(15):1-8.

Huang, Y.F., L.B. Huang, X.L. Yan, and H. Lia. 2012. Effects of phosphorus and boron coupled deficiency on soybean growth, phosphorus, boron uptake and the genetic variations. J. South China Agr. Univ. 33:129-134. <https://www. cabdirect.org/cabdirect/abstract/20123223949>.

Irfan, M., M. Abbas, J.A. Shah, N. Depar, M.Y. Memon, and N.A. Sial. 2019. Interactive effect of phosphorus and boron on plant growth nutrient accumulation and grain yield of wheat grown on calcareous soil. Eurasian J. Soil Sci. $8(1): 17-26$.

Jordan, B.R., P.E. Jatnes, A. Sttid, and R.G. Anthony. 1994. The effect of ultraviolet-B radiation on gene expression and pigment composition in etiolated and green tea leaf tissue: UV-B induced changes at-e gene specific and dependent upon the developmental stage. Plant Cell Environ. 17:45-54.

Khalifa, R., M.H. Omaima, and H. Abd-El-Khair. 2009. Influence of foliar spraying with boron and calcium on productivity, fruit quality, nutritional status and controlling of blossom end rot disease of Anna apple trees. World J. Agr. Sci. 5:237-249. <http://www.idosi.org/wjas/ wjas5(2)/17.pdf $>$.

Khan, A.S., W. Ullah, A.U. Malik, R. Ahmad, B.A. Saleem, and I.A. Rajwana. 2012. Exogenous applications of boron and zinc influence leaf nutrient status, tree growth and fruit quality of
Feutrell's early (Citrus reticulata Blanco). Pak. J. Agr. Sci. 49:113-119. <http://www.pakjas. com.pk/Citrus-EffectofBandZinc_PJAS.pdf>.

Khan, S.A., S.U. Kha, A. Qayyum, A.R. Gurmani, A. Khan, S.M. Khan, W. Ahmed, A. Mehmood, and A.Z. Amin. 2019. Integration of humic acid with nitrogen wields an auxiliary impact on physiological traits, growth and yield of maize (Zea mays L.) verities. Appl. Ecol. Environ. Res. 17:6783-6799.

Khattab, M.M., A.E. Shaban, A. El-Shrief, and A. Mohamed. 2012. Effect of humic acid and amino acids on pomegranate trees under deficit irrigation. I: Growth, flowering and fruiting. J. Hort. Sci. Ornam. Plants 4:253-259.

Khayyat, M., E. Tafazoli, S. Eshghi, and S. Rajaee. 2007. Effect of nitrogen, boron, potassium and zinc sprays on yield and fruit quality of date palm. American-Eurasian J. Agr. Environ. Sci. 2:289-296. <http://citeseerx.ist.psu.edu/viewdoc/download? doi $=10.1 .1 .629 .8548 \& \mathrm{rep}=$ rep1\& type $=$ pdf $>$.

Kiba, T., T. Kudo, M. Kojima, and H. Sakakibaran. 2011. Hormonal control of nitrogen acquisition: Roles of auxin, abscisic acid, and cytokinin. J. Exp. Bot. 62:1399-1409.

Klute, A. and C. Dirksen. 1986. Hydraulic conductivity and diffusivity: Laboratory methods, p. 687-734. In: A. Klute (ed.). Methods of soil analysis, Part 1. Physical and mineralogical methods. 2nd ed. Agronomy Monographs. 9(1). American Society of Agronomy, Madison, WI.

Koshioka, M., J.M. Harada, T. Noma, T. Sassa, K. Ogiama, S. Taylor, S.B. Rood, R.L. Legge, and R.P.K. Pharis. 1983. Reversed-phase $\mathrm{C}_{18}$ high performance liquid chromatography of acidic and conjugated gibberellins. J. Chromatography 256:101-115.

Kumar, P., A.K. Misra, and D.R. Modi. 2011. Current status of mango malformation in India. Asian J. Plant Sci. 10:1-23.

Kumar, R. and V. Kumar. 2016. Physiological disorders in perennial woody tropical and subtropical fruit-crops, A review. Indian J. Agr. Sci. 86:703-717. <http://krishi.icar.gov.in/jspui/ handle/123456789/4324>.

Lakshmipathi, J.D., D. Adiga, B. Kalaivanan, M. Muralidhara, and P. Preethi. 2018. Effect of zinc and boron application on leaf area, photosynthetic pigments, stomatal number and yield of cashew. Intl. J. Curr. Microbiol. Appl. Sci. 7:1786-1795.

Lee, K.H., H.L. Piao, H.Y. Kim, S.M. Choi, F. Jiang, W. Hartung, I. Hwang, J.M. Kwak, I.J. Lee, and I. Hwang. 2006. Activation of glucosidase via stress-induced polymerization rapidly increases active pools of a abscisic acid. Cell 126:1109-1120.

Lei, Z., Z. Min, and C. Baocheng. 2009. Effects of co-operant use of boron and phosphorus on growth and quality of Brassica napus L. Chinese Agr. Sci. Bull. 5:173-177. <http://en.cnki.com.cn/ Article_en/CJFDTotal-ZNTB200905036.htm>.

Liakopoulos, G. and G. Karabourniotis. 2005. Boron deficiency and concentrations and composition of phenolic compounds in Olea europaea leaves: A combined growth chamber and field study. Tree Physiol. 25:307-315.

Manas, D., P.K. Bandopadhyay, A. Chakravarty, S. $\mathrm{Pal}$, and A. Bhattacharya. 2014. Effect of foliar application of humic acid, zinc and boron on biochemical changes related to productivity of pungent pepper (Capsicum aпnиит L.). Afr. J. Plant Sci. 8:320-335.

Marschner, P. 2012. Marschner's mineral nutrition of higher plants. 3rd ed. Academic Press, London, UK. 
Masroor, H.M., M.A. Anjum, S. Hussain, S. Ejaz, S. Ahmad, S. Ercisli, and M. Zia-Ul-Haq. 2016. Zinc ameliorates fruit yield and quality of mangoes cultivated in calcareous soils. ErwerbsObstbau 58:49-55.

Mengel, K. and E.A. Kirkby. 2001. Principles of plant nutrition. 5th ed. Dordrechit: Kluwer Academic Publishers, Amsterdam, The Netherlands.

Merwad, M.A., R.A. Eisa, and M.M.S. Saleh. 2016. The beneficial effect of NAA, Zn, Ca and $\mathrm{B}$ on fruiting, yield and fruit quality of Alphonso mango trees. Intl. J. Chemtech Res. 9:147-157. <http://www.sphinxsai.com/2016/ ch_vo19_no3/1/(147-157)V9N3CT.pdf > .

Mohamadineia, G., H.F. Mehdin, and D. Mehdi. 2015. Foliar and soil drench application of humic acid on yield and berry properties of 'Askari' grapevine. Agr. Commun. 3(2):21-27. $<$ http://www.agricommun.com/content/archive \%20volumes/volume\%203_2/Agri.\%20Commun.\% 203_2_.pdfs.

Mosa, W.F.A., N.A. Abd EL-Megeed, and L.S. Paszt. 2015. The effect of the foliar application of potassium, calcium, boron and humic acid on vegetative growth, fruit set, leaf mineral, yield and fruit quality of 'Anna' apple trees. Amer. J. Exp. Agr. 8:224-234.

Mouco, M.A.C., M.A.C. Lima, A.L. DeSilva, S.C.A. DaSantos, and F.M. Rodrigues. 2009. Amino acids on mango yield and fruit quality at Submedio Sao Francisco Region, Brazil. Acta Hort. (820:437-442.

Nabati, D.A. 1991. Responses of two grass species to plant growth regulators, fertilizer $\mathrm{N}$, chelated $\mathrm{Fe}$, salinity and water stress. CSES. Virginia Tech, Blacksburg, VA. PhD dissertation. < https:// vtechworks.lib.vt.edu/bitstream/handle/10919/ 39783/LD5655.V856_1991.N322.pdf>.

Nanjo, T., M. Kobayashi, Y. Yoshiba, Y. Sanada, K. Wada, and H. Tsukaya. 1999. Biological functions of proline in morphogenesis and osmotolerance revealed in antisense transgenic Arabidopsis thaliana. Plant J. 18:185-193.

Nardi, S., A. Muscolo, S. Vaccaro, S. Baiano, R. Spaccini, and A. Piccolo. 2007. Relationship between molecular characteristics of soil humic fractions and glycolytic pathway and krebs cycle in maize seedlings. Soil Biol. Biochem. 39:3138-3146.

Negi, S.S., A.K. Singh, and C.P. Singh. 2009. Effect of foliar application of nutrients on fruitset, yield and quality of mango cv. Dashehari. Haryana J. Hort. Sci. 38:20-22. <https://www. cabdirect.org/cabdirect/abstract/20133355463>.

Ngullie, C.R., R.V. Tank, and D.R. Bhander. 2014. Effect of salicylic acid and humic acid on flowering, fruiting, yield and quality of mango (Mangifera indica L.) cv. KESAR. Adv. Res. J. Crop Improv. 5:136-139.

Nicander, B., U. Stahl, P.O. Bjorkman, and E. Tillberg. 1993. Immunoaffinity co-purification of cytokinies and analysis by high-performance liquid chromatography with ultra violet spectrum detection. Plant J. 189:312-320.

Nyomora, A.M.S. and P.H. Brown. 1999. Rate and time of boron application increase almond productivity and tissue boron concentration. HortScience 34:242-245.

Oka, M., Y. Shimoda, N. Sato, J. Inoue, T. Yamazaki, N. Shimomura, and H. Fujiyama. 2012. Abscisic acid substantially inhibits senescence of cucumber plants (Cucumis sativus) grown under low nitrogen conditions. J. Plant Physiol. 169:789-796.

Omar, A.H. and A.H. Abdelall. 2005. Influence of sulphuric acid, humic acid, sulphur and irrigation water on growth and productivity of superior seedless vines grown under saline condition. J. Agr. Sci. Mansoura Univ. 30: 6951-6961.

Oyinlola, E.Y. 2007. Effect of boron fertilizer on yield and oil content of three sunflower cultivars in the Nigerian savanna. J. Agron. 6:421-426.

Ozyigit, I.I., M.V. Kahraman, and O. Ercan. 2007. Relation between explant age, total phenols and regeneration response of tissue cultured cotton (Gossypium hirsutum L). Afr. J. Biotechnol. 6:3-8.

Pablo Morales, J.P. and M.S. William. 2003. Effect of substrates, boron and humic acid on the growth of papaya transplant. Proc. Annu. Meet. Fla. State Hort. Soc. 116:28-30. <http://vivo. uprm.edu/individual/n18408>.

Patrick, J.W. and P.F. Wareing. 1973. Auxinpromoted transport of metabolites in stems of Phaseolus vulgaris L.: Some characteristics of the experimental transport systems. J. Expt. Bot. 24:1158-1171.

Perica, S., P.H. Brown, J.H. Connell, A.M.S. Nyomora, C. Dordas, and H. Hu. 2001. Foliar boron application improves flower fertility and fruit set of olive. HortScience 36(4):714-716.

Pilbeam, D.J. and E.A. Kirkby. 1983. The physiological role of boron in plants. J. Plant Nutr. 6(7):563-582.

Pommerrenig, B., K. Eggert, and G.P. Bienert. 2019. Boron deficiency effects on sugar, ionome, and phytohormone profiles of vascular and non-vascular leaf tissues of common plantain (Plantago major L.). Intl. J. Mol. Sci. 20:3882.

Quaggiotti, S., B. Ruperti, D. Pizzeghello, O. Francioso, V. Tugnoli, and S. Nardi. 2004. Effect of low molecular size humic substances on the expression of genes involved in nitrate transport and reduction in maize (Zea mays L.). J. Expt. Bot. 55:803-813.

Rajpar, I., M.B. Bhatti, A.N. Zia-ul-Hassan, and S.D. Tunio. 2011. Humic acid improves growth, yield and oil content of Brassica compestris L. Pak. J. Agr., Agr. Eng. Vet. Sci. 27:125-133. <https://www.researchgate.net/ publication/230846587>.

Ramirez, F. and T.L. Davenport. 2012. Reproductive biology (physiology) — the case of mango, p. 56-81. In: S.G. Valavi, K. Rajmohan, J.N. Govil, K.V. Peter, and G. Thottappilly (eds.). Mango: Production and processing technology. Studium Press, New Delhi, India. <https://www. researchgate.net/publication/259756341>.

Rashmi, P., R. Sing, and C.P. Pantnagar. 2007. Effect of preharvest foliar spray of micronutrients on chemical properties of mango fruit cv. Langra. J. Res. 5:56-61. <http:// agris.fao.org/agris-search/search.do?recordID= IN2011000828>.

Ratthaphol, M., C. Peerasak, and W. Pheravut. 2017. Calcium-boron addition promotes pollen germination and fruit set of mango. Intl. J. Fruit Sci. 17:147-158.

Riad, M. 1997. Mango production in Egypt. Acta Hort. (455:2-6.

Rosed, H. 1957. A modified ninhydrin colorimetric analysis for amino acids. Arch. Biochem. Biophys. $67: 10-15 .<$ http://eprints.icrisat.ac.in/id/ eprint $/ 5864>$.

Saadati, S., N. Moallemi, S.M.H. Mortazavi, and S.M. Seyyednejad. 2013. Effects of zinc and boron foliar application on soluble carbohydrate and oil contents of three olive cultivars during fruit ripening. Scientia Hort. 164:30-34.

Saini, H., V. Sourabh, and P. Saini. 2019. Differential responses of $\mathrm{Fe}, \mathrm{Zn}, \mathrm{B}, \mathrm{Cu}$ and $\mathrm{Mg}$ on growth and quality attributes of fruit crops. J.
Pharm. Phytochem. 8(5):1-5. <http://www. phytojournal.com/archives/2019/vol8issue5/PartA/ 7-3-300-830.pdf $>$.

Saker, B.C. and M.A. Rahim. 2013. Yield and quality of mango (Mangifera indica L.) as influenced by foliar application of potassium nitrate and urea. Bangladesh J. Agr. Res. 38:145-154.

Sandip, M., A.N. Makwana, A.V. Barad, and B.D. Nawade. 2015. Physiology of flowering - The case of mango. Intl. J. Appl. Res 1(11):1008 1012. <http://www.allresearchjournal.com/ archives/2015/vollissue11/PartO/1-111-2.pdf $>$.

Sarrwy, S.M.A., E.G. Gadalla, and E.A.M. Mostafa. 2012. Effect of calcium nitrate and boric acid sprays on fruit set, yield and fruit quality of cv. Amhat date palm. World J. Agr. Sci. 8:506-515.

Saruhan, V., A. Kusvuran, and S. Babat. 2011. The effect of different humic acid fertilization on yield and yield components performances of common millet (Panicum miliaceum L.). Sci. Res. Essays 6:663-669. <https://academicjournals.org/SRE/PDF/pdf2011/4Feb/Saruhan\% 20et\%20al.pdf>.

Schmidt, W., S. Santi, R. Pinton, and Z. Varanini. 2007. Water-extractable humic substances alter root development and epidermal cell pattern in Arabidopsis. Plant Soil J. 300:259-267.

Shaban, A.E.A. 2009a. Effect of summer pruning and $\mathrm{GA}_{3}$ spraying on inducing flowering and fruiting of Zebda mango trees. World J. Agr. Sci. 5:337-344. <http://www.idosi.org/wjas/ wjas5(3)/13.pdf $>$.

Shaban, A.E.A. 2009b. Vegetative growth cycles of some mango cultivars in relation to flowering and fruiting. World J. Agr. Sci. 5:751-759. $<$ https://www.researchgate.net/publication/ 242589309>.

Shinde, A.K., B.P. Patil, K.H. Pujari, B.B. Jadhav, A.B. Chandelkar, and M.P. Kandalkar. 2006. Investigations on the control of fruit drop in Alphonso mango. Indian J. Plant. Physiol. 11:93-99. <https://www.semanticscholar.org/ paper/91409513>.

Sindha, D.J., B.N. Satodiya, and N.K. Sutariya. 2018. Effect of foliar application of different chemicals and humic acid on fruit yield and quality of custard apple (Annona squamosal L.) cv. Local. Intl. J. Chem. Studies. 6(5):75-77. $<$ http://www.chemijournal.com/archives/2018/ vol6issue5/PartB/6-4-514.pdf>.

Singh, D.K., P.K. Paul, and S.K. Ghosh. 2005. Response of papaya to foliar application of boron, zinc and their combinations. Res. Crops. $6(2): 277-280$.

Singh, R.N. 1971. Biennial bearing in fruit treesaccent on mango and apples. Indian Council Agr. Res. Technol. Bull. 30:47 < http://www.nicraicar.in/nicrarevised/index.php/seasonal-bulletin>.

Singh, R.R. and C.B.S. Rajput. 1976. Effect of various concentrations of zinc on vegetative growth characters, flowering, fruiting and physio-chemical composition of fruits in mango (Mangifera indica L.) cv. Chausa. Haryana J. Hort. Sci. 5(1-2):10-14.

Smith-Ramirez, C., J.J. Armesto, and J. Figueroa. 1998. Flowering, fruiting and seed germination in Chilean rain forest myrtaceae: Ecological and phylogenetic constraints. Plant Ecol. 136: 119-131.

Snedecor, G.W. and W.G. Cochran. 1980. Statistical methods. 7th ed. Iowa State University Press, Ames, IA.

Song, C.Z., M.Y. Liu, J.F. Meng, M. Chi, Z. Xi, and Z.W. Zhang. 2015. Promoting effect of foliage sprayed zinc sulfate on accumulation of sugar and phenolics in berries of Vitis vinifera $\mathrm{cv}$. 
merlot growing on zinc deficient soil. Molecules 20:2536-2554.

Srivastava, P.C. and U.C. Gupta. 1996. Essential trace elements in crop production, p. 73-173. In: P.C. Srivastava and U.C. Gupta (eds.). Trace elements in crop production. Oxford \& IBH Publishing Cop. Pvt. Ltd., New Delhi, India.

Trevisan, S., A. Botton, S. Vaccaro, A. Vezzaro, S. Quaggiotti, and S. Nardi. 2011. Humic substances affect Arabidopsis physiology by altering the expression of genes involved in primary metabolism, growth and development. Environ. Exp. Bot. 74:45-55.

Turkmen, O., A. Dursun, M. Turan, and C. Erdinc. 2004. Calcium and humic acid affect seed germination, growth, and nutrient content of tomato (Lycopersicon esculentum L.) seedlings under saline soil conditions. Acta Agr. Scandinavica. 54:168-174.

Umesh, R., R. Rupa, K. Ravindra, B.K. Mandal, and K.K. Prasad. 2010. Effect of foliar application of urea, borax and zinc on flowering, fruiting and fruit quality of Amrapali mango. Environ. Ecol. 28(3):1668-1671.

UNCTAD. 2016. Mango: An infocomm commodity profile. In: United Nations Conference on Trade and Development (UNCTAD), United Nations, New York, NY; Geneva, Switzerland. $<$ https://unctad.org/en/PublicationsLibrary/ INFOCOMM_cp07_Mango_en.pdf $>$.

Upreti, K.K., Y.T.N. Reddy, S.R. Shivuprasad, G.V. Bindu, H.L. Jayaram, and S. Rajan. 2013. Hormonal changes in response to paclobutrazol induced early flowering in mango cv. Totapuri. Sci. Hort. 150:414-418.

Uraguchi, S. and T. Fujiwara. 2011. Significant contribution of boron stored in seeds to initial growth of rice seedlings. Plant Soil 340:435-442.
Usenik, V. and F. Stampar. 2002. Effect of foliar application of zinc plus boron on sweet cherry fruit set and yield. Acta Hort. 594(28):245-249.

Van Oosten, M.J., O. Pepe, S. De Pascale, S. Silletti, and A. Maggio. 2017. The role of biostimulants and bioeffectors as alleviators of abiotic stress in crop plants. Chem. Biol. Technol. Agr. 4:1-5.

Vaughan, D. and B.G. Ord. 1981. Uptake and incorporation of ${ }^{14} \mathrm{C}$-labelled soil organic matter by roots of Pisum sativum L. J. Expt. Bot. 32:679-687.

Vejendla, V., P.K. Maity, and B.C. Banik. 2008. Effect of chemicals and growth regulators on fruit retention, yield and quality of mango $\mathrm{cv}$. Amrapali. J. Crop Weed. 4(2):45-46. <http:// www.cropandweed.com/vol4issue2/pdf2005/ 12.pdf $>$.

Whily, A.W., T.S. Rasmussem, J.B. Saranah, and B.N. Wolstenholme. 1989. Effect of temperature on growth, dry matter production and starch accumulation in ten mango (Mangifera indica L.) cultivars. J. Hort. Sci. Biotechnol. 64:753-765.

Wilde, S.A., R.B. Corey, J.G. Lyer, and G.K. Voigt. 1979. Soil and plant analysis for tree culture. 5th ed. Oxford \& IBH publishing Co., New Delhi, India. <https://www.cabdirect.org/ cabdirect/abstract/19861909795>.

Wojcik, P. and M. Wojcik. 2003. Effect of boron fertilization on 'Conference' pear tree vigor, nutrition, and fruit yield and storability. Plant Soil J. 256:413-421.

Wolf, S., D. Van der Does, F. Ladwig, C. Sticht, A. Kolbeck, A.K. Schurholz, S. Augustin, N. Keinath, T. Rausch, and S. Greiner. 2014. A receptor-like protein mediates the response to pectin modification by activating brassinosteroid signaling. Proc. Natl. Acad. Sci. USA 111:15261-15266.
Woo, J., C.R. MacPherson, J. Liu, H. Wang, T. Kiba, M.A. Hannah, X.J. Wang, V.B. Bajic, and N.H. Chua. 2012. The response and recovery of the Arabidopsis thaliana transcriptome to phosphate starvation. BMC Plant Biol. $12: 22$.

World Weather Online. 2020. Zagazig historical weather. Egypt Historical Weather Almanac. Manchester, UK. 31 Mar. 2020. <https://www. worldweatheronline.com/lang/en-us/zagazigweather-history/ash-sharqiyah/eg.aspx>.

Yakhin, O.I., A.A. Lubyanov, I.A. Yakhin, and P.H. Brown. 2017. Biostimulants in plant science: A global perspective. Front. Plant Sci. 7:20-49.

Yua, S.K. and J. Ryan. 2008. Boron toxicity tolerance in crops: A viable alternative to soil amelioration. Crop Sci. 48:854-865.

Zagzog, O.A. and M.M. Gad. 2017. Improving growth, flowering, fruiting and resistance of malformation of mango trees using nanozinc. Middle East J. Agr. 6:673-681. <http:// www.curresweb.com/mejar/mejar/2017/673681.pdf>.

Zanin, L., N. Tomasi, S. Cesco, Z. Varanini, and R. Pinton. 2019. Humic substances contribute to plant iron nutrition acting as chelators and biostimulants. Front. Plant Sci. 10:675.

Zhou, T., Y. Hua, Y. Huang, G. Ding, L. Shi, and F. Xu. 2016. Physiological and transcriptional analyses reveal differential phytohormone responses to boron deficiency in Brassica napus genotypes. Front. Plant Sci. 7:16.

Zuo, Y., L. Ren, F. Zhang, and R.F. Jiang. 2007. Bicarbonate concentration as affected by soil water content controls iron nutrition of peanut plants in a calcareous soil. Plant Phys. Biotech. 45(5):357-364. 